\title{
Assessment of $\mathrm{MgZr}_{4} \mathrm{P}_{6} \mathrm{O}_{24}$ as a Solid Electrolyte for Sensing $\mathrm{Mg}$ in Molten Non-Ferrous Alloys
}

To cite this article: Mohammed Adamu et al 2020 J. Electrochem. Soc. 167027532

View the article online for updates and enhancements. 


\title{
Assessment of $\mathrm{MgZr}_{4} \mathbf{P}_{6} \mathrm{O}_{24}$ as a Solid Electrolyte for Sensing $\mathrm{Mg}$ in Molten Non-Ferrous Alloys
}

\author{
Mohammed Adamu, ${ }^{1, *, z_{(1)}}$ K. T. Jacob, ${ }^{2, *, z}$ (i) and Girish M. Kale ${ }^{1, z}$ (i) \\ ${ }^{1}$ School of Chemical and Process Engineering, University of Leeds, Leeds LS2 9JT, United Kingdom \\ ${ }^{2}$ Department of Materials Engineering, Indian Institute of Science, Bengaluru 560012, India
}

The potential solid electrolyte, $\mathrm{MgZr}_{4} \mathrm{P}_{6} \mathrm{O}_{24}$ was prepared using a modified sol-gel method. Both structural and electrical properties of the solid electrolyte were determined. DSC-TGA analysis indicated that pure dried xerogel when calcined at $900{ }^{\circ} \mathrm{C}$ converts to single phase $\mathrm{MgZr}_{4} \mathrm{P}_{6} \mathrm{O}_{24}$ nanopowder with good crystallinity. Pellets of $13 \mathrm{~mm}$ diameter and $3.8 \mathrm{~mm}$ thickness made by uniaxial compression were sintered at $1300{ }^{\circ} \mathrm{C}$ for $24 \mathrm{~h}$. XRD and HR-TEM indicated that the crystalline phase is monoclinic having crystallite size of approximately $40 \mathrm{~nm}$. The sintered pellets were stable in the temperature range from 1000 to $1300{ }^{\circ} \mathrm{C}$, with minor extraneous peaks indicating traces of a coexistent second phase $\left(\mathrm{Zr}_{2} \mathrm{P}_{2} \mathrm{O}_{9}\right)$ at the higher temperature. Using impedance spectroscopy, the electrical conductivity of $\mathrm{MgZr}_{4} \mathrm{P}_{6} \mathrm{O}_{24}$ was determined as $7.23 \times 10^{-3} \mathrm{Scm}^{-1}$ at $725{ }^{\circ} \mathrm{C}$. $\mathrm{MgZr}_{4} \mathrm{P}_{6} \mathrm{O}_{24}$ pellet was successfully used for fabrication of a solid-state $\mathrm{Mg}$-sensor for measuring $\mathrm{Mg}$ concentration in molten $\mathrm{Al}$ at $700 \pm 5^{\circ} \mathrm{C}$, with biphasic powder mixture of $\mathrm{MgCr}_{2} \mathrm{O}_{4}+\mathrm{Cr}_{2} \mathrm{O}_{3}$ as ceramic reference electrode in air. A linear dependence of emf on logarithm of $\mathrm{Mg}$ concentration was obtained. The results indicate that the transport number of $\mathrm{Mg}^{2+}$-cation in $\mathrm{MgZr}_{4} \mathrm{P}_{6} \mathrm{O}_{24}$ is $0.85 \pm 0.03$ at $700{ }^{\circ} \mathrm{C}$. The solid electrolyte has likely applications in high-temperature electrochemical sensors.

(C) 2020 The Electrochemical Society (“ECS”). Published on behalf of ECS by IOP Publishing Limited. [DOI: 10.1149/1945-7111/ ab6556]

Manuscript submitted August 27, 2019; revised manuscript received November 18, 2019. Published January 28, 2020.

The plethora of research interest in functional materials and characterisation is geared towards understanding the behaviour of engineering materials in operation. Today, materials function optimally in ambient and high-temperature environment, as a result, appropriate materials are selected for certain applications. Selecting materials for high-temperature application invariably requires stability of the materials as well as environmental suitability compared to applications at ambient temperatures. Selection of functional materials for high-temperature application in aggressive environment is extremely challenging.

Aluminium (Al) and magnesium $(\mathrm{Mg})$ are two important light weight structural metals that offer tremendous weight saving potential in automobiles, aerospace and defence application; they both possess the lightest density of common structural materials $\left(\rho_{\mathrm{Al}}=2.77 \mathrm{gcm}^{-3}, \rho_{\mathrm{Mg}}=1.74 \mathrm{gcm}^{-3}\right) .{ }^{1-3}$ The non-heat-treatable $\mathrm{Al}-\mathrm{Mg}$ alloys have wide ranging application in the aerospace sector whereas, the age-hardened $\mathrm{Al}-\mathrm{Mg}$-Si alloys have shown tremendous combination of strength and formability needed in automobiles. ${ }^{2}$

Production of $\mathrm{Al}$ and $\mathrm{Mg}$ from raw materials is extremely energy intensive process. Recycling and recovery of $\mathrm{Al}$ and $\mathrm{Mg}$ from their alloy scrap require only a fraction of that energy. Since the Al-alloy scrap generally contains excess $\mathrm{Mg}$ which is demagged during recycling, ${ }^{4}$ an in-line solid-state $\mathrm{Mg}$-sensor could substantially improve efficiency. Continuous monitoring the composition of the $\mathrm{Mg}$ in $\mathrm{Al}-\mathrm{Mg}$, $\mathrm{Al}-\mathrm{Mg}-\mathrm{Si}$ and other non-ferrous alloys during recycling and alloying operation, allows in-process adjustments to the alloy composition. ${ }^{5}$

Magnesium ion conducting $\mathrm{MgZr}_{4} \mathrm{P}_{6} \mathrm{O}_{24}$ ceramic has attracted attention as a solid electrolyte with potential applications in hightemperature electrochemical sensor for liquid metals and alloys, and other electrochemical devices. $\mathrm{MgZr}_{4} \mathrm{P}_{6} \mathrm{O}_{24}$ and other divalent $\mathrm{Mg}^{2+}$-conducting solid electrolytes have been studied. ${ }^{6-10}$ In a similar study, ${ }^{11,12}$ it was reported that the $\mathrm{MgZr}_{4} \mathrm{P}_{6} \mathrm{O}_{24}$ divalent cationic conductor belong to $\beta$ - $\mathrm{Fe}_{2}\left(\mathrm{SO}_{4}\right)_{3}$-type structure possessing three-dimensional skeletal structure comprising $\mathrm{PO}_{4}$ tetrahedra sharing corners with $\mathrm{ZrO}_{6}$ octahedra. ${ }^{10}$ Recently, the $\mathrm{Mg}^{2+}$-conducting behaviour of $\mathrm{MgZr}_{4} \mathrm{P}_{6} \mathrm{O}_{24}$ electrolyte was prepared by a modified sol-gel chemical method and the electrical properties characterised using impedance spectroscopy. ${ }^{13}$ The ionic conductivity of $\mathrm{MgZr}_{4} \mathrm{P}_{6} \mathrm{O}_{24}$ solid electrolyte, like the Li-ion conductivity which plays a pivotal role in determining the performance of Li-S batteries, and the effect of temperature on ionic conductivity has been proved to be significant for ceramic electrolytes. ${ }^{14}$ For example, at $725{ }^{\circ} \mathrm{C}$, the ionic conductivity of $\mathrm{MgZr}_{4} \mathrm{P}_{6} \mathrm{O}_{24}$ solid electrolyte ${ }^{13}$ is of the order of $10^{-3} \mathrm{~S} \mathrm{~cm}^{-1}$, which shows that the dependence of conductivity on temperature for ceramic electrolytes generally follows a continuous Arrhenius trend. ${ }^{14}$ In this study, however, sol-gel method was followed since it is believed to be an excellent method for synthesising precursor oxides of high purity and uniform composition. Adamu and Kale ${ }^{13}$ in a recent study identified the potential advantages of sol-gel chemical method over conventional solid-state reaction such as greater homogeneity, compositional control flexibility and lower processing temperature. Among solid electrolytes, it has been discovered that ceramic electrolytes form significant class of materials, as they display a wide range of electrochemical stability window, absence of leakage when compared to liquid electrolytes and they can be fabricated into a variety of sizes and shapes ${ }^{15,16}$ having an ordered structure. ${ }^{17}$

Nanoparticles have been used in the synthesis of solid electrolytes for the development of electrochemical sensors owing to their unique physiochemical characteristics, ${ }^{18}$ although metal nanoparticles like gold and platinum are widely used in specific low temperature sensors, but sensors based on the noble metals are less cost effective for commercial applications at elevated temperatures in aggressive environments. ${ }^{19}$ More so, the electrochemical $\mathrm{Mg}$-sensor characterised in this study is aimed at utilising the advantages of electrochemical technologies in the sensing of $\mathrm{Mg}$ concentrations in the molten non-ferrous alloys containing $\mathrm{Mg} .{ }^{20}$

In fabricating and testing the characterised high-temperature solidstate Mg-sensor, stability of the solid-state Mg-sensor was determined in molten $\mathrm{Al}$ and $\mathrm{Mg}$-Al alloys, respectively, at $700 \pm 5{ }^{\circ} \mathrm{C}$. Sensor sensitivity and its low detection limit, selectivity, and reproducibility of the solid-state $\mathrm{Mg}$-sensor are considered vital to be investigated. ${ }^{21}$ Operational stability of the oxide-based electrochemical sensor characterised in this study, like the oxidase-based biosensors, is of particular importance as it significantly improves the sensor performance and applicability in the relevant environment. ${ }^{22}$ One requirement for electromotive force (emf) measurements is that both the electrolyte and electrodes are chemically stable in the operating environment. ${ }^{23}$ Thus, emf measurements can be conveniently used to measure the more active element in an alloy, as illustrated in this study where the activity of $\mathrm{Mg}$ has been measured in molten $\mathrm{Al}$. In general, recent development in sensor technology has evolved as a result of advanced method of synthesising and processing novel functional materials, ${ }^{13,24}$ exhibiting enhanced electrochemical properties. 


\section{Experimental}

Materials preparation.-In preparation of $\mathrm{MgZr}_{4} \mathrm{P}_{6} \mathrm{O}_{24}$ solid electrolyte, a simple sol-gel chemical procedure modified by Adamu and $\mathrm{Kale}^{13}$ was followed. This chemical synthesis route produce very fine and pure nanopowders; achieved through mixing on atomic scale by combining aqueous solutions of soluble salts at a relatively low crystallisation temperature and, it produce compositions not always possible by the solid-state fusion method. The starting reagents in this study were $\mathrm{MgCO}_{3}$ (Sigma-Aldrich, $\geqslant 40 \%$ $\mathrm{MgO}$ ), Aqueous $\mathrm{HNO}_{3}$ (Sigma-Aldrich, ACS reagent, 70\%), $\mathrm{ZrOCl}_{2} \cdot 8 \mathrm{H}_{2} \mathrm{O}$ (Sigma-Aldrich, 98.5\% purity) and $\mathrm{NH}_{4} \mathrm{H}_{2} \mathrm{PO}_{4}$ (Alfa Aesar, 98\% purity). All raw materials were weighed in stoichiometric proportions and dissolved in deionised $\mathrm{H}_{2} \mathrm{O}$, better outlined in Fig. 1. Aqueous solutions of $\mathrm{Mg}\left(\mathrm{NO}_{3}\right)_{2}$ and $\mathrm{NH}_{4} \mathrm{H}_{2} \mathrm{PO}_{4}$ were prepared separately and mixed together while stirring in a beaker to form the homogeneous sol. Further, appropriate amount of aqueous $\mathrm{ZrOCl}_{2} \cdot 8 \mathrm{H}_{2} \mathrm{O}$ solution was prepared and added dropwise to the homogeneous sol using a burette to precipitate acidic whitish gel. To neutralise the mixture, $\mathrm{NH}_{4} \mathrm{OH}$ was gradually added dropwise to the homogeneous gel to adjust $\mathrm{pH}$ of the gel from 1.2 to a final $\mathrm{pH}$ of 10.2. The final solution was stirred for $1 \mathrm{~h}$ and dried at $100{ }^{\circ} \mathrm{C}$ for $24 \mathrm{~h}$ on a hot plate to achieve a dry xerogel. After drying, the dry xerogel powders were mechanically ground with agate mortar and pestle and calcined at $900{ }^{\circ} \mathrm{C}$ (heating/cooling rate, $\beta=10{ }^{\circ} \mathrm{C} \mathrm{min}^{-1}$ ) to produce single phase polycrystalline whitish $\mathrm{MgZr}_{4} \mathrm{P}_{6} \mathrm{O}_{24}$ nanopowders. The calcined nanopowders were mixed with 1 wt\% binder (Ciba Glascol HA4: Ciba speciality Chemicals, Bradford, UK) and then pressed into pellets of $13 \mathrm{~mm}$ diameter and $3.8 \mathrm{~mm}$ thickness with a uniaxial steel die at $5 \mathrm{kN}$ compressive pressure. The resultant pellet was sintered for $24 \mathrm{~h}$ at $1300{ }^{\circ} \mathrm{C}$ (heating/cooling rate, $\beta=10^{\circ} \mathrm{C} \mathrm{min}{ }^{-1}$ ) in a closed alumina crucible immersed in powder of the same composition. Prior to reaching the sintering temperature of the samples, the binder is burnt out between 400 and $450{ }^{\circ} \mathrm{C}$.

Materials characterisation.-To determine an optimum calcination temperature for $\mathrm{MgZr}_{4} \mathrm{P}_{6} \mathrm{O}_{24}$ dry gel powders, simultaneous DSC-TGA was performed on $\mathrm{MgZr}_{4} \mathrm{P}_{6} \mathrm{O}_{24}$ dry xerogel powders. The thermal oxidation behaviour and weight loss of the dried gel powders were determined by STA 8000 (PerkinElmer, Seer Green, UK) in order to ensure effective optimisation of calcination conditions of the dried gel powders in a controlled atmosphere at a flow rate of $50 \mathrm{~mL} \mathrm{~min}^{-1}$ using a constant heating/cooling rate, $\beta=10{ }^{\circ} \mathrm{C} \min ^{-1}$ between 30 and $1000{ }^{\circ} \mathrm{C}$. For phase analysis, calcined powders and sintered pellets of $\mathrm{MgZr}_{4} \mathrm{P}_{6} \mathrm{O}_{24}$ were examined using powder X-ray diffractometer (Bruker D8 advance, Karlsruhe, GmbH) equipped with $\mathrm{Cu} \mathrm{K}_{\alpha}$ (with $\lambda=1.5406 \AA$ ) radiation source operating at $30 \mathrm{kV}$ and $45 \mathrm{~mA}$ and calibrated against $\mathrm{Si}$ standard. XRD data was collected over $10^{\circ} \leqslant 2 \theta \leqslant 80^{\circ}$ scan range. The unit-cell lattice parameters of the calcined powder and their Rietveld fits were determined using program GSAS $^{25}$ with EXPGUI interface. ${ }^{26}$ For measurement of electrical properties, sintered $\mathrm{MgZr}_{4} \mathrm{P}_{6} \mathrm{O}_{24}$ solid electrolyte pellets were mildly ground to achieve a flat surface without significantly altering the pellet thickness. Platinum paste (Sigma-Aldrich, UK) was lightly applied to the opposite parallel faces of the sintered pellet and allowed to dry before firing in a tube furnace at $800{ }^{\circ} \mathrm{C}$ for $0.5 \mathrm{~h}$ to form contact electrodes. The electrical conductivity was recorded as a function of temperature and frequency using impedance analyser, Solartron SI1260 FRA (Hampshire, UK) in the temperature range from 197 to $764{ }^{\circ} \mathrm{C}$ and frequency range from $100 \mathrm{mHZ}$ to $32 \mathrm{MHz}$. Microstructural examinations were performed on carbon-coated fractured pellet using scanning electron microscopy, SEM (Carl Zeiss EVO MA15, Jena, GmbH) equipped with energy-dispersive X-ray spectroscopy and Oxford Aztec X-Act EDS spectrometer. After following standard procedure of sample preparation, TEM (FEI Titan ${ }^{3}$ Themis 300, Cambridge, UK) was used to determine

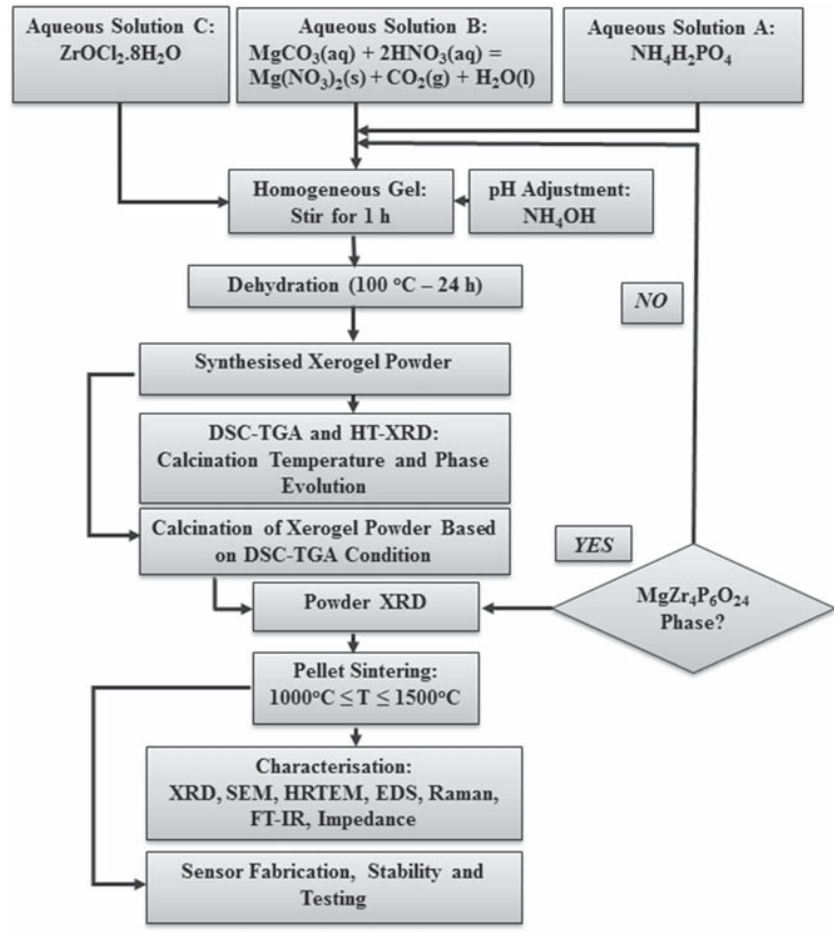

Figure 1. Flowchart showing the sol-gel chemical synthesis procedures.

surface morphology, crystalline phase, lattice fringes and elemental composition of $\mathrm{MgZr}_{4} \mathrm{P}_{6} \mathrm{O}_{24}$ sample. Precision location of component elements in $\mathrm{MgZr}_{4} \mathrm{P}_{6} \mathrm{O}_{24}$ were also identified using the TEM fitted with high-angle annular dark field (HAADF) detector operated at an accelerating voltage of $300 \mathrm{kV}$ equipped with energy dispersive X-ray spectroscopy (EDS, Oxford INCA 350). The TEM data were analysed using Velox application software.

Sensor fabrication and testing.-The general fabrication process of solid-state $\mathrm{Mg}$-sensor is outlined in Fig. 2. A simple Mg-probe was firstly produced using a $13 \mathrm{~mm}$ diameter and $3.8 \mathrm{~mm}$ thickness sintered composite solid electrolyte pellet attached to an open end of a $50.8 \mathrm{~mm}$ long alumina tube using pure alumina refractory cement (Parkinson-Spencer Refractories Ltd, Halifax). A $0.25 \mathrm{~mm}$ thick annealed $\mathrm{Fe}-\mathrm{Cr}$ alloy wire (Goodfellow, Cambridge) was coiled, inserted and rammed down into bottom of the alumina tube along with a biphasic mixture of $\mathrm{MgCr}_{2} \mathrm{O}_{4}+\mathrm{Cr}_{2} \mathrm{O}_{3}$ which served as the reference electrode. The solid-state $\mathrm{Mg}$-probe was extended by inserting it into a $120 \mathrm{~mm}$ ceramic tube and holding it firm with an alumina refractory cement to form a bulk solid-state $\mathrm{Mg}$-sensor. Under a purified argon gas environment, the solid-state Mg-sensor was immersed into $560 \mathrm{~g}$ pure molten $\mathrm{Al}$ and eutectic mixture of $\mathrm{NaCl}$ and $\mathrm{KCl}$ salts at $700 \pm 5{ }^{\circ} \mathrm{C}$ held in a high density alumina crucible. The thin layer of salt-melt protected molten $\mathrm{Al}$ from oxidation. A $350 \mathrm{~mm}$ long and $2 \mathrm{~mm}$ diameter Mo-rod (Goodfellow, Cambridge) sheathed inside an alumina tube and sealed at both ends, served as an electrical lead to molten Al. The annealed Fe-Cr alloy wire extension from the reference electrode of the $\mathrm{Mg}$-sensor was then connected to the positive terminal of a 10-channel Keithley 6517 A digital electrometer while the Mo-rod was connected to the negative terminal ensuring continuous recording of the cell voltage and temperature of the metal by a computer-controlled multi-channel high-impedance $\left(\geqslant 10^{13} \Omega\right)$ electrometer. After long equilibration of the $\mathrm{Mg}$-sensor in pure molten $\mathrm{Al}$ to determine the test baseline, change in $\mathrm{Mg}$ content in molten $\mathrm{Al}$ during the tests was made in situ by adding $\mathrm{Mg}$ wrapped in $\mathrm{Al}$ foil to the pure metal in regulated steps in the range from 0.005 to $1.5 \mathrm{wt} \% \mathrm{Mg}$. The temperature was 


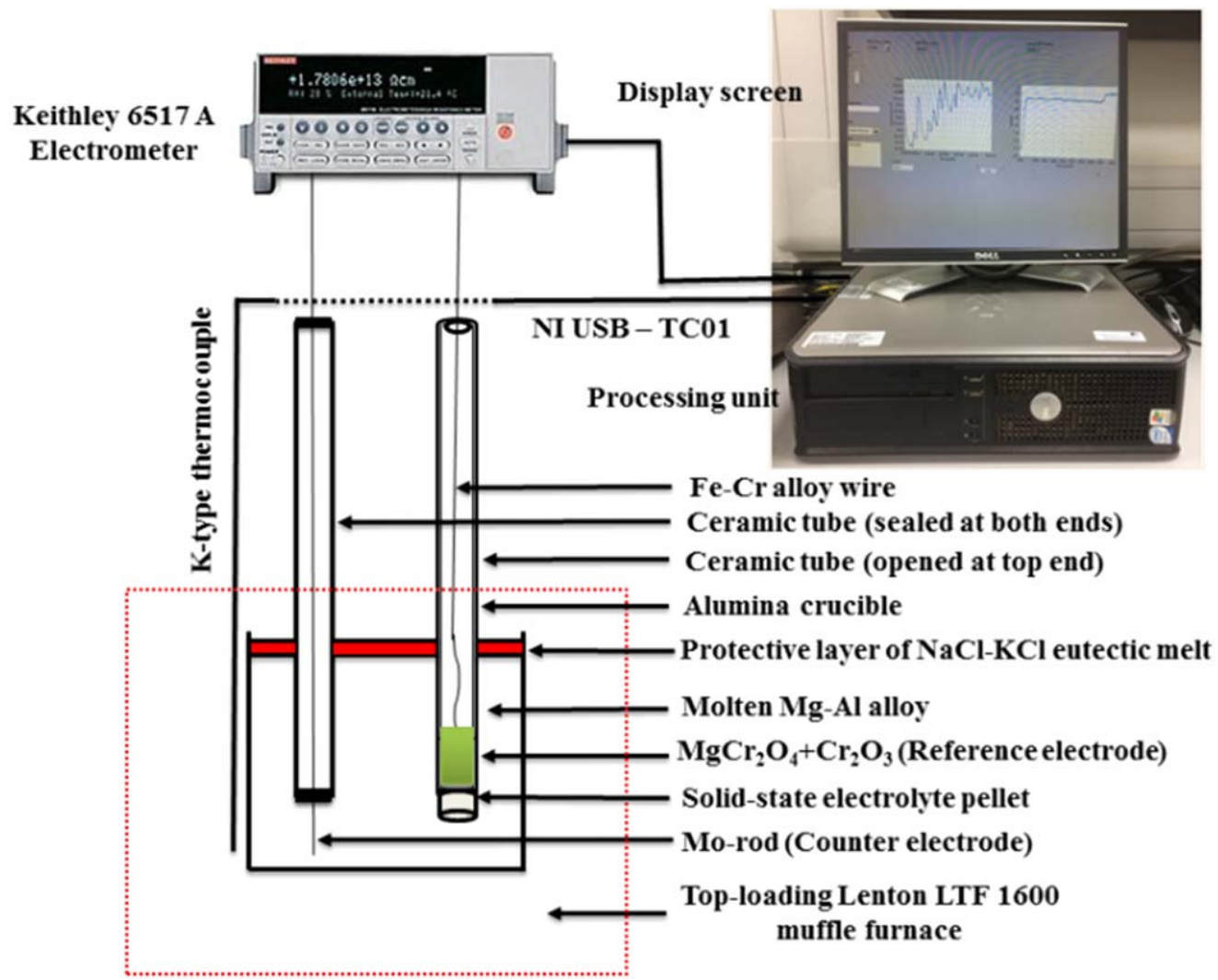

Figure 2. A schematic of the solid-state $\mathrm{Mg}$-sensor test rig.

monitored using the K-type thermocouple inserted in the top-loading Lenton LTF 1600 muffle furnace connected through NI USB-TC01 temperature input device (Business Park, Newbury) to LabVIEW interface monitoring real time temperature as shown in Fig. 2. When the emf became stable after each $\mathrm{Mg}$ addition, suction samples were withdrawn from the melt using a silica tube of $2 \mathrm{~mm}$ diameter. The $\mathrm{Mg}$ concentration of the samples was determined with the Atomic Absorption Spectrometer (AAS), Aanalyst 400 (PerkinElmer, Waltham, USA). The magnesium sensor fabricated in this study is based on the basic principle similar to the potentiometric antimony sensor with the difference that the latter requires an oxide-ion conducting solid electrolyte. ${ }^{23}$

\section{Results and Discussion}

Simultaneous DSC-TGA.-The thermal behaviour of $\mathrm{MgZr}_{4} \mathrm{P}_{6} \mathrm{O}_{24}$ xerogel powders was earlier studied by Adamu and Kale, ${ }^{13}$ with measurements ranging from 30 to $1000{ }^{\circ} \mathrm{C}$, showing a mass loss and thermal decomposition of the dried xerogel powders in flowing air at $50 \mathrm{c.c}$. $\mathrm{min}^{-1}$ and heating rate of $10{ }^{\circ} \mathrm{C} \mathrm{min}-1$. It was reported that the TGA curve shows progressive mass loss of the dried xerogel powders in the range from 30 to $500{ }^{\circ} \mathrm{C}$ and stabilisation between 750 and $870{ }^{\circ} \mathrm{C}$. The mass loss from $99.9 \%$ to $62.65 \%$ and the associated endothermic peaks are attributed to loss of $\mathrm{H}_{2} \mathrm{O}$ and decomposition of precursor materials such as $\mathrm{NH}_{4} \mathrm{H}_{2} \mathrm{PO}_{4}, \mathrm{Mg}\left(\mathrm{NO}_{3}\right)_{2}, \mathrm{ZrOCl}_{2} \cdot 8 \mathrm{H}_{2} \mathrm{O}$. $\mathrm{NH}_{4} \mathrm{H}_{2} \mathrm{PO}_{4}$ decomposes to $\mathrm{P}_{2} \mathrm{O}_{5}, \mathrm{H}_{2} \mathrm{O}$, and $\mathrm{NH}_{3}$ at $190{ }^{\circ} \mathrm{C}, \mathrm{Mg}\left(\mathrm{NO}_{3}\right)_{2}$ to $\mathrm{MgO}, \mathrm{NO}_{2}$, and $\mathrm{O}_{2}$ at $330{ }^{\circ} \mathrm{C}$, and $\mathrm{ZrOCl}_{2} \cdot 8 \mathrm{H}_{2} \mathrm{O}$ to $\mathrm{ZrO}_{2}, \mathrm{HCl}$, and $\mathrm{H}_{2} \mathrm{O}$ at $437{ }^{\circ} \mathrm{C}$. The exothermic peak between 870 and $900{ }^{\circ} \mathrm{C}$ signals the formation of $\mathrm{MgZr}_{4} \mathrm{P}_{6} \mathrm{O}_{24}$ from reactive oxides $\mathrm{MgO}, \mathrm{P}_{2} \mathrm{O}_{5}$, and $\mathrm{ZrO}_{2}$ formed in situ. The precursor residues, namely $\mathrm{NH}_{4} \mathrm{Cl}, \mathrm{HCl}, \mathrm{HNO}_{3}$, and $\mathrm{H}_{2} \mathrm{O}$ indicated in Eq. 1, vaporise during calcination enabling the formation of pure single phase $\mathrm{MgZr}_{4} \mathrm{P}_{6} \mathrm{O}_{24}$.

$$
\begin{aligned}
& \mathrm{Mg}\left(\mathrm{NO}_{3}\right)_{2}(\mathrm{aq})+4 \mathrm{ZrOCl}_{2} \cdot 8 \mathrm{H}_{2} \mathrm{O}(\mathrm{aq})+6 \mathrm{NH}_{4} \mathrm{H}_{2} \mathrm{PO}_{4}(\mathrm{aq}) \\
&= \mathrm{MgZr}_{4} \mathrm{P}_{6} \mathrm{O}_{24}(\mathrm{~s})+6 \mathrm{NH}_{4} \mathrm{Cl}(\mathrm{aq})+2 \mathrm{HCl}(\mathrm{aq})+2 \mathrm{HNO}_{3}(\mathrm{aq}) \\
& \quad+36 \mathrm{H}_{2} \mathrm{O}(\mathrm{l})
\end{aligned}
$$

$X$-ray diffraction.-The formation temperature of the $\mathrm{MgZr}_{4} \mathrm{P}_{6} \mathrm{O}_{24}$ indicated by the simultaneous DSC-TGA analysis was confirmed by high-temperature XRD (HT-XRD). XRD patterns of nanopowder calcined at $900{ }^{\circ} \mathrm{C}$ and pellets sintered at $1300{ }^{\circ} \mathrm{C}$ have been reported. ${ }^{13}$ The pattern of calcined nanopowders agreed well with that of monoclinic $\mathrm{Mg}_{0.5} \mathrm{Zr}_{2}\left(\mathrm{PO}_{4}\right)_{3}$ [ICDD-04-016-0487] which shows a single phase. The sintered pellet however shows the presence of minor coexistent second phase, evident for example at $22.54^{\circ} 2 \theta$. The minor phase is identified as orthorhombic $\mathrm{Zr}_{2}\left(\mathrm{PO}_{4}\right)_{2} \mathrm{O}$ [ICDD-04-011-6948]. Hence, the pellet sintered at $1300{ }^{\circ} \mathrm{C}$ may be considered as a composite solid electrolyte based on $\mathrm{MgZr}_{4} \mathrm{P}_{6} \mathrm{O}_{24}$. These findings are consistent with the observations of Pet'kov et al. ${ }^{7}$ and Kazakos-Kijowski et al. ${ }^{27}$ When heated in the temperature range $1350 \leqslant \mathrm{~T} /{ }^{\circ} \mathrm{C} \leqslant 1500, \mathrm{MgZr}_{4} \mathrm{P}_{6} \mathrm{O}_{24}$ is found to decompose to orthorhombic $\mathrm{Zr}_{2} \mathrm{P}_{2} \mathrm{O}_{9}$ and a liquid phase. The composition of the liquid phase changes with sintering temperature and time because of the vaporisation of $\mathrm{P}_{2} \mathrm{O}_{5}$. As calcination temperature increases from 800 to $900{ }^{\circ} \mathrm{C}$, the average crystallite size obtained using Scherrer equation ${ }^{28-31}$ also increases from $32 \pm 2 \mathrm{~nm}$ to $39 \pm 2 \mathrm{~nm}$. The pellets sintered at $1300{ }^{\circ} \mathrm{C}$ shows an optimum density from densification analysis of sintered pellets as a function of temperature.

The XRD pattern at $25{ }^{\circ} \mathrm{C}$ of the nanopowder calcined at $900{ }^{\circ} \mathrm{C}$ was refined (Fig. 3). The refined parameters and corresponding Rfactor are presented in Table I. Atomic coordinates, site occupancies and displacement parameters are given in Table II. The crystal 


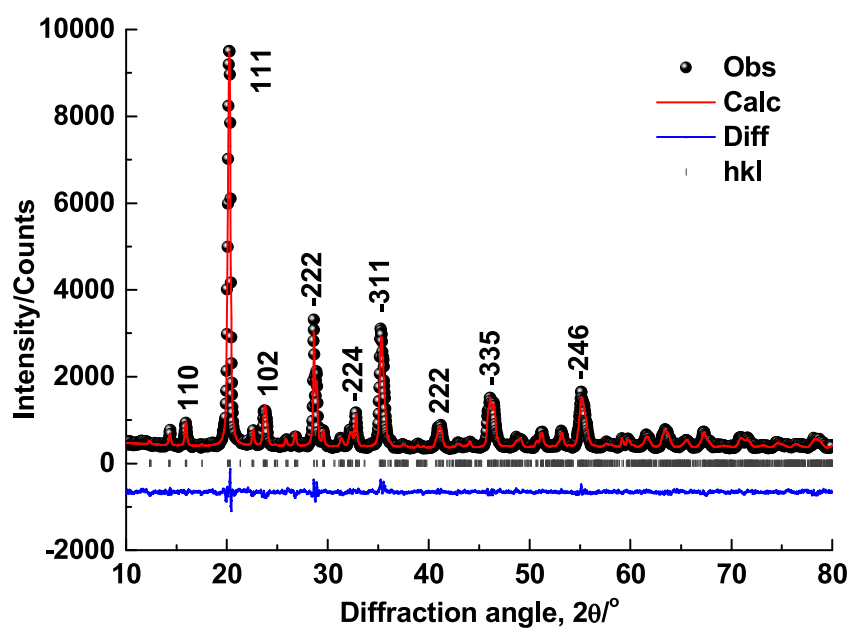

Figure 3. Experimental (black sphere) and calculated (red line) XRD peak profile of $\mathrm{MgZr}_{4} \mathrm{P}_{6} \mathrm{O}_{24}$ and the difference between the experimental and calculated spectra (blue bottom line). Dark grey vertical bars indicate allowed Bragg reflection positions of the calculated XRD peaks profile

structure and lattice cell parameters agree well with those in ICDD04-016-0487: $\mathrm{a}(\AA)=12.4218(2), \mathrm{b}(\AA)=8.9025(2), \mathrm{c}(\AA)=8.8218$ (2), $\beta(\mathrm{deg})=90.4660(1), \mathrm{V}\left(\AA^{3}\right)=975.53(2)$. The differences in unit cell parameters are quite minimal.

HR-TEM of $\mathrm{MgZr}_{4} \mathrm{P}_{6} \mathrm{O}_{24}$ nanopowders. - The particle morphologies and lattice crystal structures of $\mathrm{MgZr}_{4} \mathrm{P}_{6} \mathrm{O}_{24}$ nanoparticles was investigated using high-resolution TEM (HR-TEM) and corresponding SAED. The micrograph in Fig. 4 shows two different lattice fringes attributed to [21-2] and [110] interplanar spacing of $\mathrm{MgZr}_{4} \mathrm{P}_{6} \mathrm{O}_{24}$ nanoparticles with some amorphous layer surrounding the crystalline particles. The crystal lattice fringes corresponding to $3.9038 \AA$ and $5.6820 \AA$ atomic spacing, are characteristics of monoclinic $\mathrm{MgZr}_{4} \mathrm{P}_{6} \mathrm{O}_{24}$. The d-spacing of the surface grafting nanoparticles in Fig. 4ai and Fig. 4aii shows trend of core crystallinity. The SAED pattern in Fig. 4aiii can be indexed to the (100) zone axes of monoclinic $\mathrm{MgZr}_{4} \mathrm{P}_{6} \mathrm{O}_{24}$, testifying to homogeneity and pure single phase of the nanoparticles. The d-spacing values obtained from SAED patterns in Fig. 4aiii compares well with the XRD data achieved in this study, comparable with an earlier study. ${ }^{13}$

Figure 5 depicts the corresponding elemental map of $\mathrm{MgZr}_{4} \mathrm{P}_{6} \mathrm{O}_{24}$ nanopowders. The spectra in the maps show uniform spatial distribution of $\mathrm{Mg}, \mathrm{Zr}, \mathrm{P}$, and $\mathrm{O}$ with the corresponding atomic ratio in $\mathrm{MgZr}_{4} \mathrm{P}_{6} \mathrm{O}_{24}$ indicating homogeneous phase as

Table I. The unit cell characteristics and results of the Rietveld refinement for the crystal structure of $\mathrm{MgZr}_{4} \mathrm{P}_{6} \mathrm{O}_{24}$ sample at $25{ }^{\circ} \mathrm{C}$ (The standard deviation in units of the last decimal is presented in brackets).

Space group, Z

Radiation

Wavelength, ^

$2 \theta$ scan range, deg

Unit cell parameters:

a, $\AA$

b, $\AA$

c, $\AA$

$\beta, \operatorname{deg}$

$\mathrm{V}, \AA^{3}$

Number of reflections

Refinement parameters

Residual values, \%:

$\mathrm{R}_{\mathrm{wp}}$

$\mathrm{R}_{\mathrm{p}}$

$\chi^{2}$
$\mathrm{P} 2_{1 / \mathrm{n}}, 4$

$\mathrm{CuK} \alpha \mathrm{X}$-ray

1.54056

$10-80$

$12.3850(8)$

$8.8775(6)$

$8.8001(7)$

90.529(5)

967.52(12)

198

18

5.43

4.25

1.680
Table II. Atomic coordinates, site occupancies $q$, and displacement parameters of $U_{\text {iso }} / U_{e} * 100$ in $\operatorname{MgZr}_{4} P_{6} O_{24}$ structures.

\begin{tabular}{lccccc} 
Atom & $\mathrm{x}$ & $\mathrm{y}$ & $\mathrm{z}$ & $\mathrm{U}_{\text {iso }} / \mathrm{U}_{\mathrm{e}} * 100$ & $\mathrm{q}$ \\
\hline 11 & 0.1616 & 0.2183 & 0.7182 & 12.21 & 0.6902 \\
$\mathrm{Zr}(1)$ & 0.1153 & 0.0293 & 0.2530 & 2.52 & 1.0000 \\
$\mathrm{Zr}(2)$ & 0.3882 & 0.0290 & 0.7466 & 1.50 & 1.0000 \\
$\mathrm{P}(1)$ & 0.4864 & 0.2846 & 0.4500 & 4.92 & 0.6292 \\
$\mathrm{P}(2)$ & 0.1481 & 0.3731 & 0.3848 & 5.96 & 0.7925 \\
$\mathrm{P}(3)$ & 0.3537 & 0.3838 & 0.8720 & 9.89 & 0.7905 \\
$\mathrm{O}(1)$ & 0.5570 & 0.2953 & 0.5872 & 14.61 & 1.0000 \\
$\mathrm{O}(2)$ & 0.5768 & 0.1783 & 0.3516 & 4.13 & 1.0000 \\
$\mathrm{O}(3)$ & 0.3875 & 0.3820 & 0.2995 & 6.65 & 1.0000 \\
$\mathrm{O}(4)$ & 0.4796 & 0.1333 & 0.5788 & 12.41 & 1.0000 \\
$\mathrm{O}(5)$ & 0.1918 & 0.2035 & 0.3488 & 7.25 & 1.0000 \\
$\mathrm{O}(6)$ & 0.0395 & 0.4268 & 0.3542 & 11.86 & 1.0000 \\
$\mathrm{O}(7)$ & 0.1379 & 0.4241 & 0.5780 & 13.63 & 1.0000 \\
$\mathrm{O}(8)$ & 0.2024 & 0.4983 & 0.2618 & 9.43 & 1.0000 \\
$\mathrm{O}(9)$ & 0.3311 & 0.2305 & 0.8198 & 12.85 & 1.0000 \\
$\mathrm{O}(10)$ & 0.3746 & 0.3586 & 0.0556 & 5.56 & 1.0000 \\
$\mathrm{O}(11)$ & 0.4529 & 0.4608 & 0.8191 & 2.71 & 1.0000 \\
$\mathrm{O}(12)$ & 0.2526 & 0.5475 & 0.8331 & 9.05 & 1.0000
\end{tabular}

evident in Fig. 5 which agrees with XRD patterns in this study as presented in Table III.

Table III shows EDS spectrum of $\mathrm{MgZr}_{4} \mathrm{P}_{6} \mathrm{O}_{24}$ nanoparticles with non-stoichiometric concentration. For instance, dividing through by 2.73 shows less concentration of $\mathrm{Zr}$ while, $\mathrm{P}$ and $\mathrm{O}$ are in excess of standard concentration. However, the nanoparticles shows uniformity in terms of spatial distribution of the maps.

Electrical conductivity_Impedance analysis._Fast ionic conductors attract attention as an indispensable material for the development of next generation energy systems, chemical sensors and other electrochemical devices. ${ }^{32}$ For the ionic conductivity, a pure single phase electrolyte powder with a high surface area is required. ${ }^{33}$ However, to incorporate this material as a solid electrolyte in fabricating electrochemical sensor, highly dense sintered ceramic is needed. ${ }^{33}$ The results of impedance analysis of the $\mathrm{MgZr}_{4} \mathrm{P}_{6} \mathrm{O}_{24}$ pellet obtained by two-probe method in the temperature range from 197 to $764{ }^{\circ} \mathrm{C}$ and frequency range from $100 \mathrm{mHz}$ to $32 \mathrm{MHz}$ are presented in Fig. 6 showing electrical properties of the solid electrolyte which qualifies it as $\mathrm{Mg}^{2+}$-cationic conductor. The ac-impedance method allows contribution from the grain interior, grain boundaries, and electrode-electrolyte interface to electrical conductivity of the sample. Figures $6 \mathrm{a}-6 \mathrm{~b}$ demonstrates impedance measurements at both low and high-temperatures with the electric modulus showing various relaxation points at different temperatures suggesting a conduction mechanism which is a thermally activated type of correlated hopping of $\mathrm{Mg}^{2+}$-cations. The impedance spectra in Fig. 6a however shows a single slightly depressed semicircle at higher frequency followed by the low-frequency spike inclined at $45^{\circ}$, and the border frequency, $\mathrm{f}_{\mathrm{b}}$ separating both the high and low-frequency regions, was observed at frequency region $50.7 \mathrm{kHz}$ and $12.7 \mathrm{kHz}$, respectively, for low and high-temperature impedance analysis. The inclined spike at low frequencies of $\mathrm{MgZr}_{4} \mathrm{P}_{6} \mathrm{O}_{24}$ solid electrolyte shows it as cationic

Table III. Average elemental composition spectra of $\operatorname{MgZr}_{4} \mathbf{P}_{6} \mathrm{O}_{24}$ nanoparticles.

\begin{tabular}{lcc} 
Element & Atomic Fraction $(\%)$ & Atomic Ratio \\
\hline $\mathrm{Mg}$ & 2.73 & 1.00 \\
$\mathrm{Zr}$ & 9.34 & 3.42 \\
$\mathrm{P}$ & 17.94 & 6.57 \\
$\mathrm{O}$ & 69.99 & 25.64 \\
Total & 100.00 &
\end{tabular}




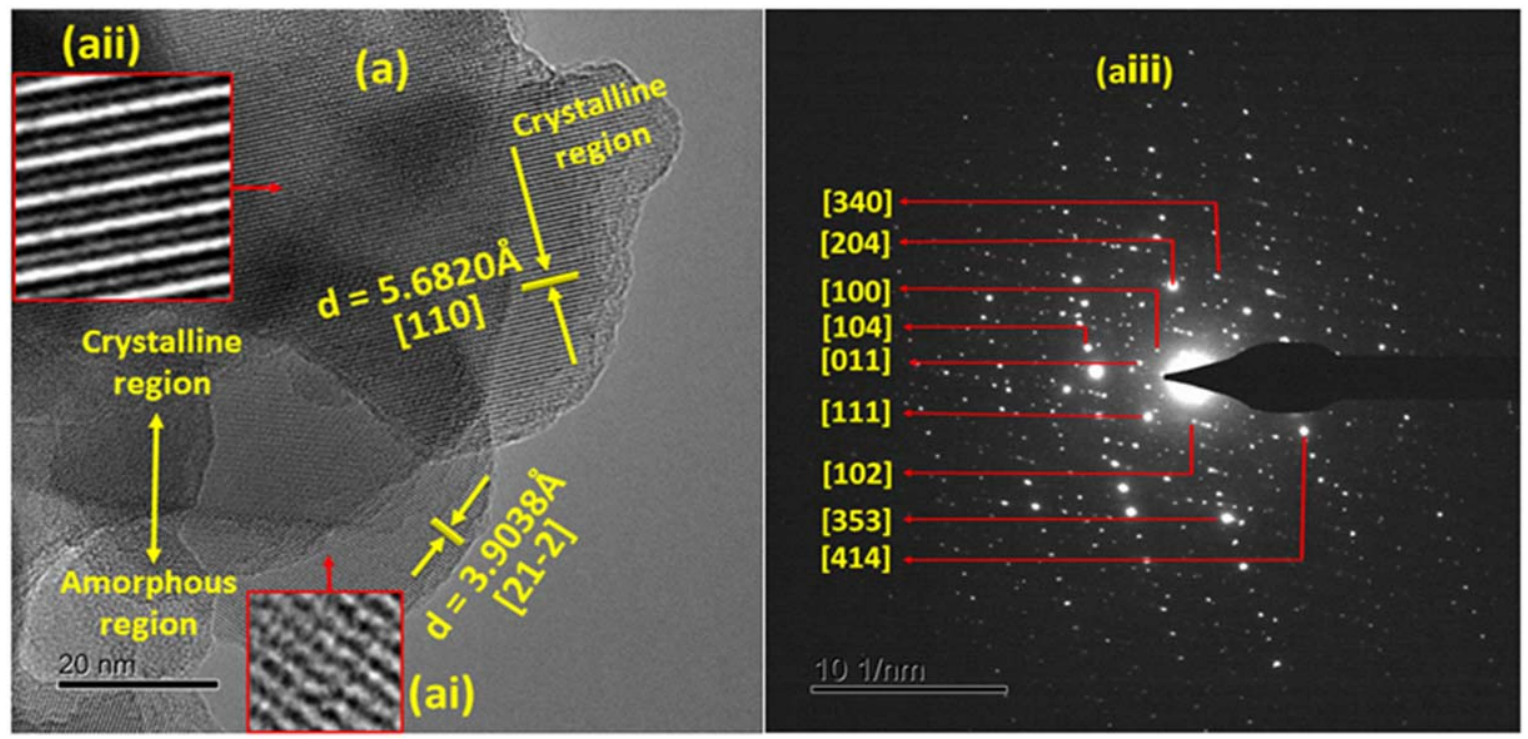

Figure 4. HR-TEM micrograph image and corresponding SAED patterns for (a-aiii) $\mathrm{MgZr}_{4} \mathrm{P}_{6} \mathrm{O}_{24}$ nanoparticles prepared by calcining the precursor xerogel at $800{ }^{\circ} \mathrm{C}$ for $0.5 \mathrm{~h}$ showing details of d-spacing from lattice fringes of HR-TEM and SAED patterns.

conductor $^{34,35}$ and the slightly depressed semicircle attributed to constant phase element (CPE) parameter appears to suggest the nonDebye relaxation type, ${ }^{36}$ similar to solid electrolytes studied earlier ${ }^{37}$ since the centre of the depressed semicircle is located below the real axis. However, the inclined spike in low-frequency region may be attributed to the polarisation effect at the electrode-electrolyte interface. ${ }^{38}$ The semicircle in Figs. $6 \mathrm{a}$ and $6 \mathrm{~b}$ can be expressed in terms of an equivalent circuit built from a combination of resistance, $R_{p}$ and capacitance, $\mathrm{C}_{\mathrm{p}}$ with a $\mathrm{CPE}^{39}$ relation as;

$$
Z=\frac{1}{C(j \omega)^{n}}
$$

Using the CPE relation in Eq. 2, C representing an ideal capacitance iff $\mathrm{n}=1, \mathrm{j}=(-1)^{1 / 2}$ and $\omega$ is the angular frequency. In real terms, the equivalent circuit consists of a series combination of parallel RC circuit elements and a series resistor, $\mathrm{R}_{\mathrm{s}}$. Grain resistance denotes a lumped resistance, while grain boundary resistance is represented by a resistance attached in parallel to a capacitor. ${ }^{40}$

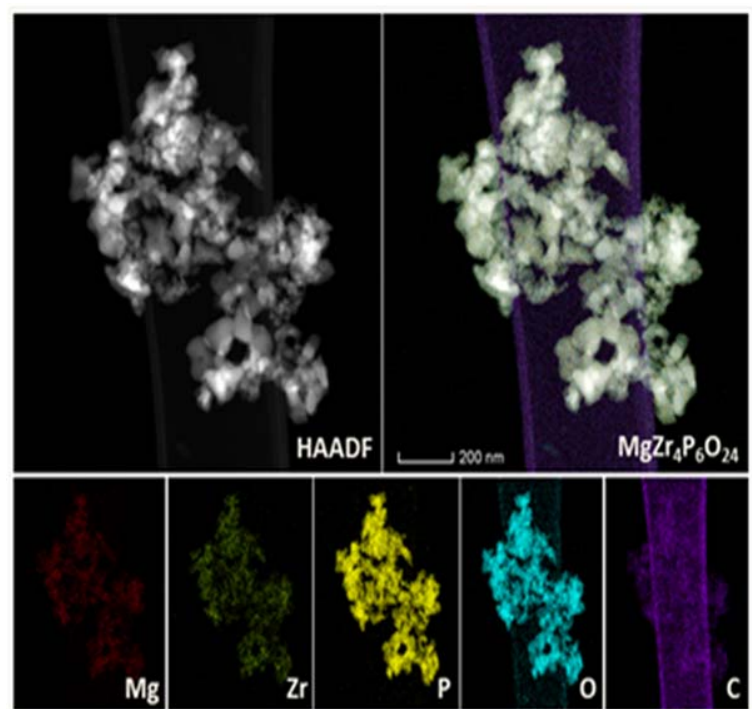

As impedance analysis temperature increases from 390 to $764{ }^{\circ} \mathrm{C}$, the depressed bulk semicircle gradually became smaller relative to the inclined spike. This shows that as bulk resistance, $R_{b}$ is decreasing, the reversibility of charge migration of the electrode-electrolyte, interface is increasing. ${ }^{41}$ The semicircle in Fig. $6 \mathrm{~b}$ however, started off the origin indicating there is a finite resistance, $\mathrm{R}_{\mathrm{s}}$ representing lumped electrodeelectrolyte interfacial resistance in series with a parallel combination of $\mathrm{R}_{\mathrm{b}}$ and $\mathrm{CPE}_{\mathrm{b}}$ which represents a grain resistance and constant phase element as presented in Fig. $6 \mathrm{c}$.

The capacitance, $\mathrm{C}$ of the solid electrolyte was calculated at different temperature as outlined in Fig. 6, using frequency, $\mathrm{f}$ at the maximum point of the semicircle. In using the relation, $\mathrm{C}=(2 \pi \mathrm{fR})^{-1}$ where $\mathrm{f}$ and $\mathrm{R}$ represent the frequency and resistance of electroceramics, the capacitance and related interpretation is outlined in Table IV:

Temperature dependence of ac-conductivity.-The linearity plot presented in Fig. 7 shows ionic conductivity of $\mathrm{MgZr}_{4} \mathrm{P}_{6} \mathrm{O}_{24}$ solid electrolyte at different temperature. The linearity of the plot suggests

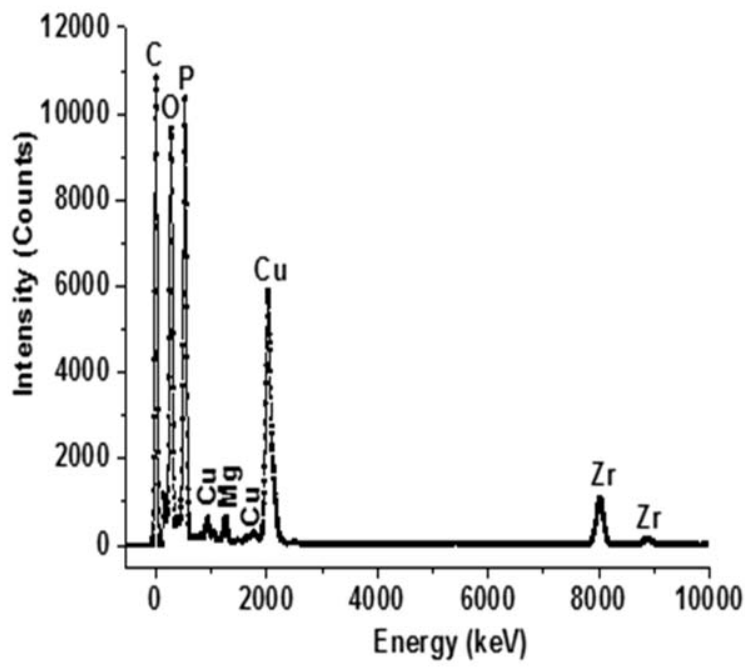

Figure 5. HAADF and EDS elemental maps of $\mathrm{MgZr}_{4} \mathrm{P}_{6} \mathrm{O}_{24}$ nanopowders calcined at $800{ }^{\circ} \mathrm{C}$ for $0.5 \mathrm{~h}$. 

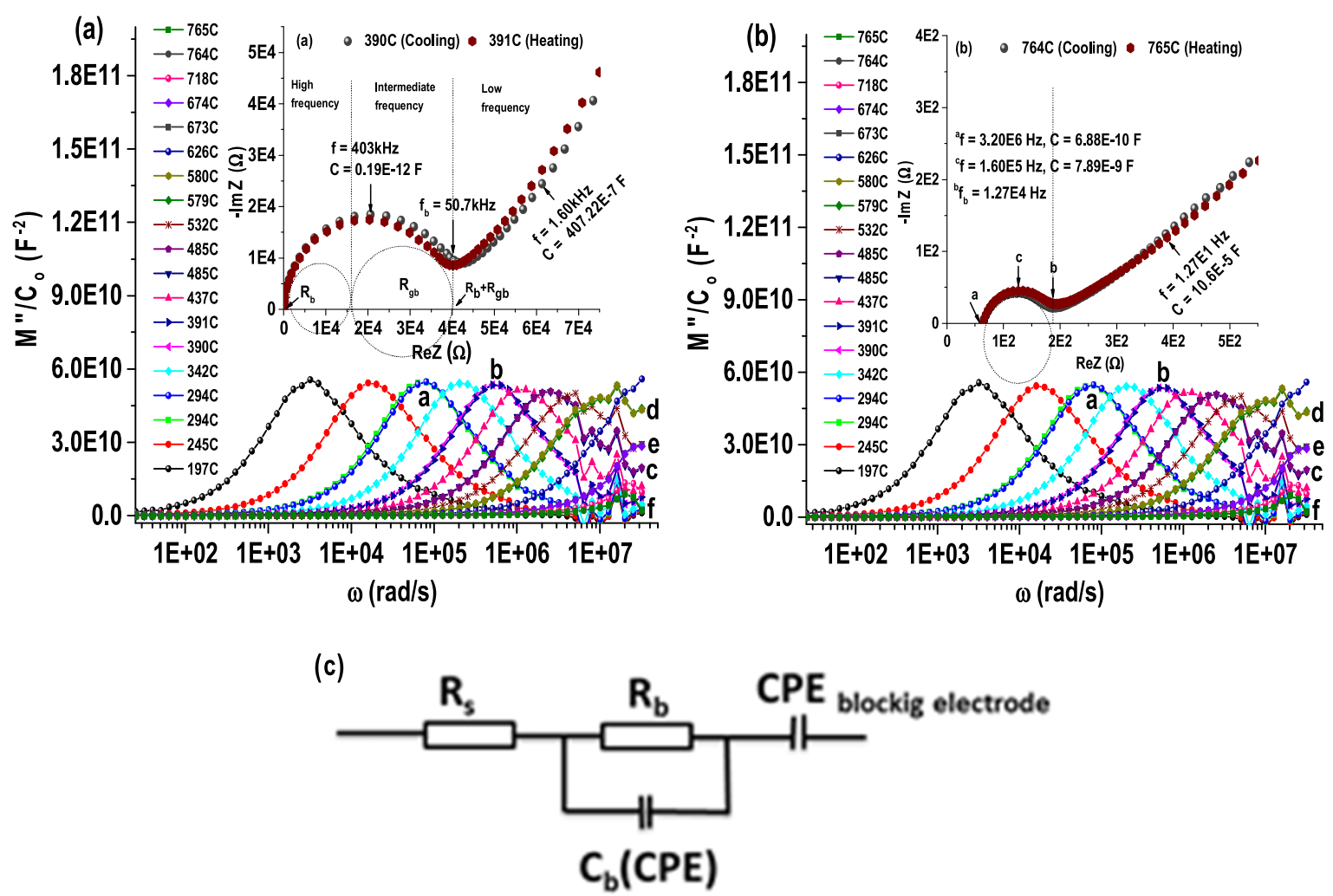

Figure 6. Electric modulus and Nyquist plots of $\mathrm{MgZr}_{4} \mathrm{P}_{6} \mathrm{O}_{24}$ solid electrolyte at (a) 390 and $391{ }^{\circ} \mathrm{C}$ and (b) 764 and $765{ }^{\circ} \mathrm{C}$ in $100 \mathrm{mHz}-32 \mathrm{MHz}$ frequency range. $* \mathrm{f}_{\mathrm{b}}$ is border frequency of the Nyquist plots. *inscription a-f showing reproducibility behaviour of the solid electrolyte. (c) The equivalent circuit of $\mathrm{MgZr}_{4} \mathrm{P}_{6} \mathrm{O}_{24}$ sample measured at $390{ }^{\circ} \mathrm{C}-391{ }^{\circ} \mathrm{C}$, and $764{ }^{\circ} \mathrm{C}-765{ }^{\circ} \mathrm{C}$.

there is no significant phase changes within $197{ }^{\circ} \mathrm{C}-764{ }^{\circ} \mathrm{C}$ temperature range of measurement. This also suggest $\mathrm{MgZr}_{4} \mathrm{P}_{6} \mathrm{O}_{24}$ solid electrolyte as a good ionic conducting material. The activation energy, $\mathrm{E}_{\mathrm{a}}$ was determined from the gradient of Arrhenius plot by fitting the ac-conductivity data with the Arrhenius equation as presented;

$$
\sigma T=\operatorname{Aexp}\left(-\frac{E_{a}}{k T}\right)
$$

where $\sigma$ is the total conductivity, A is the pre-exponential factor, $E_{a}$ is the activation energy for conduction, $k$ is the Boltzmann constant and $T$ is temperature $(\mathrm{K})$.

Based on the relation between Eq. 3 and the data of this study, ionic conduction as a thermally activated transport, shows that conductivity increases exponentially as temperatures increase. In this study therefore, the $\mathrm{MgZr}_{4} \mathrm{P}_{6} \mathrm{O}_{24}$ solid electrolyte shows a bulk conductivity of $7.23 \times 10^{-3} \mathrm{Scm}^{-1}$ at $725{ }^{\circ} \mathrm{C}$, which is a slight improvement on $6.92 \times 10^{-3} \mathrm{Scm}^{-1}$ at $800{ }^{\circ} \mathrm{C}$ achieved in an earlier study. ${ }^{42}$ The activation energy, $\mathrm{E}_{\mathrm{a}}$ of the solid electrolyte, calculated from the slope of $\ln \sigma_{\mathrm{dc}} \mathrm{T}-1000 \mathrm{~T}^{-1}$ plot in Fig. 7 equates to $0.84 \pm 0.04 \mathrm{eV}$. It shows $\mathrm{MgZr}_{4} \mathrm{P}_{6} \mathrm{O}_{24}$ solid electrolyte with low $\mathrm{E}_{\mathrm{a}}$ which of course provides a shorter profile of $\mathrm{Mg}^{2+}$-cationic mobility thereby resulting in an improved conductivity.
Frequency dependence of ac-conductivity.-Frequency dependence of the real impedance ( $\mathrm{ReZ}$ ) for $\mathrm{MgZr}_{4} \mathrm{P}_{6} \mathrm{O}_{24}$ solid electrolyte at different temperatures is presented in Fig. 8. The ac-conductivity dispersion plots of $\mathrm{MgZr}_{4} \mathrm{P}_{6} \mathrm{O}_{24}$ solid-state electrolyte shows three regions of interest (i) low-frequency dispersion, (ii) intermediatefrequency plateau, and (iii) extended dispersion at high frequency. ${ }^{43-46}$ The low-frequency dispersions in ac-conductivity correspond to electrode polarisation at the electrode-electrolyte interface. $^{38}$ At this frequency, the ionic conductivity of $\mathrm{MgZr}_{4} \mathrm{P}_{6} \mathrm{O}_{24}$ is high enough to accumulate a significant amount of charge at the electrode-electrolyte interface, which reduces the effective applied field across the measured sample resulting in possible conductivity. ${ }^{47-49}$

Intermediate-frequency plateau represents the dc-conductivity and does not depend on frequency, but on temperature, which agrees excellently with conductivity relationship in Fig. 8. The switch over from the intermediate-frequency region to the extended dispersion region at high frequency signals the onset of conductivity relaxation, which shifts toward higher frequencies as the temperature increases, representing ac-ion conductivity. The observed dispersion of this conductivity with frequency agrees with the prediction of the jump relaxation model in solid electrolytes. ${ }^{50}$ According to this model, as frequencies tend to zero ( $\mathrm{f} \rightarrow 0$ ), ion can jump from one

Table IV. Capacitance values and their possible interpretation.
\begin{tabular}{lcccl} 
& & & \\
Solid Electrolyte & Frequency $(\mathrm{Hz})$ & Resistance $(\omega)$ & Capacitance $(\mathrm{F})$ & Phenomenon Responsible \\
\hline $\mathrm{MgZr}_{4} \mathrm{P}_{6} \mathrm{O}_{24}\left(390^{\circ} \mathrm{C}-391{ }^{\circ} \mathrm{C}\right)$ & $4.03 \times 10^{5}$ & $2.08 \times 10^{6}$ & $0.19 \times 10^{-12}$ & bulk \\
$45^{\circ}$ electrode spike & $1.60 \times 10^{3}$ & $2.44 \times 10^{1}$ & $407.22 \times 10^{-7}$ & sample-electrode interface \\
$\mathrm{MgZr}_{4} \mathrm{P}_{6} \mathrm{O}_{24}\left(764^{\circ} \mathrm{C}-765^{\circ} \mathrm{C}\right)$ & $3.20 \times 10^{6}$ & $7.23 \times 10^{1}$ & $688.0 \times 10^{-12}$ & bulk \\
& $1.60 \times 10^{5}$ & $1.26 \times 10^{2}$ & $7.89 \times 10^{-9}$ & grain boundary \\
$45^{\circ}$ electrode spike & $1.27 \times 10^{1}$ & $11.82 \times 10^{1}$ & $10.6 \times 10^{-5}$ & sample-electrode interface
\end{tabular}




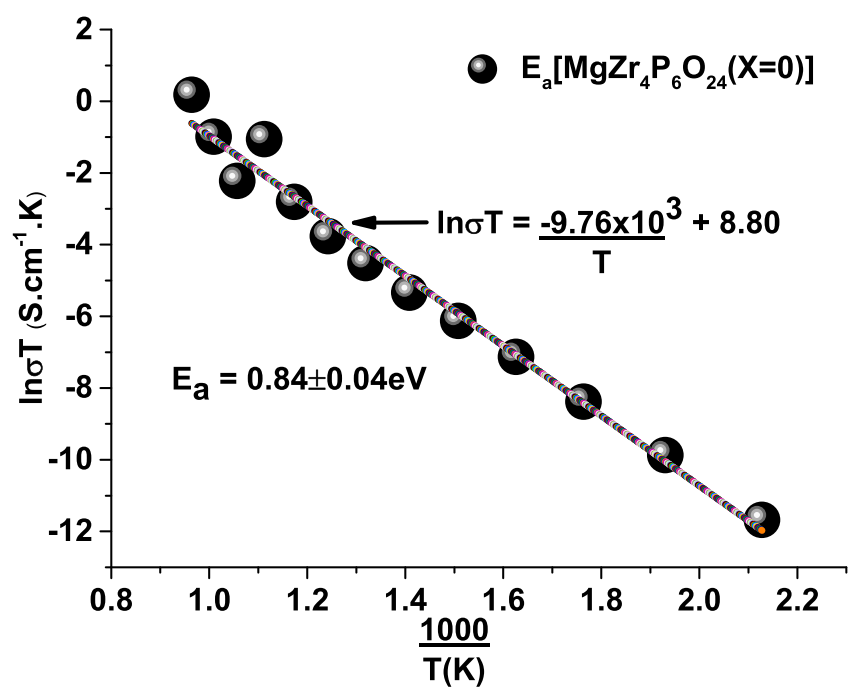

Figure 7. Bulk ionic conductivity of $\mathrm{MgZr}_{4} \mathrm{P}_{6} \mathrm{O}_{24}$ solid-state electrolyte as a function of temperature.

site to another neighbouring vacant site which contributes to ac-conductivity. ${ }^{50}$ However, at high frequencies, the probability of the ion to jump back to its initial site increases due to available short time frame. The high probability for the correlated forward-backward hopping at high frequencies together with the relaxation of the dynamic cage potential is responsible for the high frequency dispersion. ${ }^{51}$ In any case, since the crossover frequency is temperature dependent, it can be observed in Fig. 8 that the crossover frequencies, $\omega_{\mathrm{p}}$, shift towards high-frequency as temperature increases. Meanwhile, the logarithmic plot between dc-conductivity and crossover frequency, $\omega_{\mathrm{p}}$, in Fig. 8 insert gives a slope of 1 which agrees with conductivity formalism, ${ }^{50}$ which implies that both dcand ac-conductions are closely correlated and that they are of same mechanism, ${ }^{52}$ alternatively, the characteristic angular frequency, $\omega_{\mathrm{p}}$, is activated with the same thermal activation energy as dc-conductivity. ${ }^{49,50,52,53}$

At high-frequency dispersion, angular frequency-dependent acconductivity, $\sigma_{\mathrm{ac}}(\omega)$ increases and is well described by the Jonscher universal power law formulated as ${ }^{45,54}$

$$
\sigma_{\mathrm{ac}}(\omega)=\sigma_{\mathrm{dc}}+\mathrm{A} \omega^{\mathrm{n}}
$$

where $\sigma_{\mathrm{ac}}(\omega)$ is the ac-conductivity, $\sigma_{0}$ is the limiting zero frequency conductivity $\left(\sigma_{\mathrm{dc}}\right)$ of the electrolyte, $\mathrm{A}$ is the pre-exponential constant, $\omega=2 \pi \mathrm{f}$ is the angular frequency and $\mathrm{n}$ is the power law

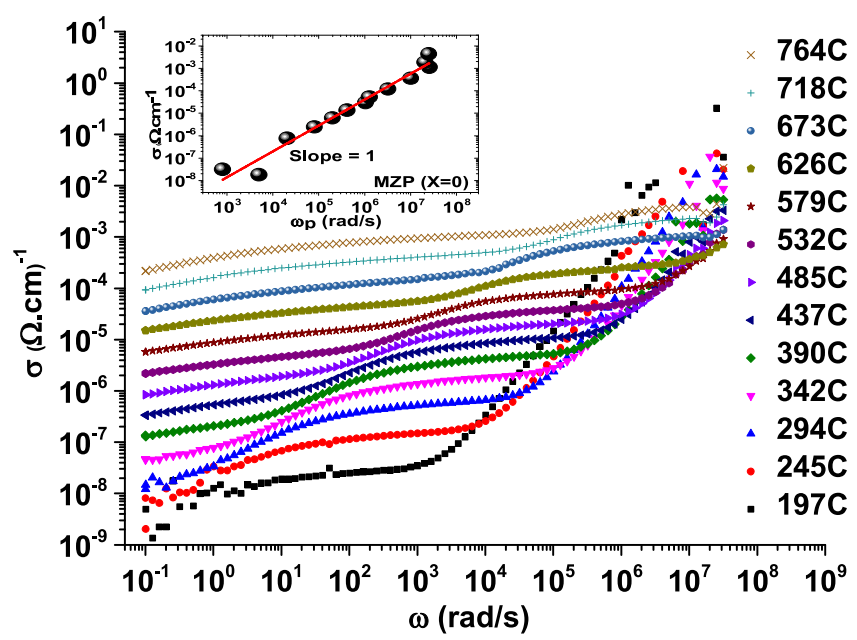

Figure 8. The ac-conductivity dispersion plots of $\mathrm{MgZr}_{4} \mathrm{P}_{6} \mathrm{O}_{24}$ solid-state electrolyte at various temperatures. Insert is a plot of $\log \sigma$ vs $\log \omega_{\mathrm{p}}$. exponent which represents the degree of interaction between the mobile ion and is less than $1(0<n<1){ }^{46}$ The value of $n$ is extracted from the slope of $\log \sigma_{\mathrm{ac}}(\omega)$ vs $\log \omega$ when $\sigma_{0} \rightarrow$ zero. Furthermore, the conductance spectra in Fig. 8 shows that when measurement temperature increases, the transition from the dcconductivity plateau to ac-conductivity dispersion region shifts towards higher frequency range $\left(10^{3}-10^{7} \mathrm{rad} \mathrm{s}^{-1}\right)$. At high frequencies, the conductance spectra at different temperatures converge thus indicating that ac-conductivity is independent of temperature at high frequencies. ${ }^{55-58}$

A comparison of dc-conductivity from the intermediatefrequency plateau with ac-conductivity using Arrhenius relation is presented in Fig. 9. The close correlation in the total conductivity depicts that the conduction is from the same majority charge carrier, $\mathrm{Mg}^{2+}$-cation, and that the composite solid electrolyte is purely ionic. This equally suggest a reasonably high transference number for $\mathrm{Mg}^{2+}$-cation in $\mathrm{MgZr}_{4} \mathrm{P}_{6} \mathrm{O}_{24}$ solid electrolyte as well as their comparable activation energy, $\mathrm{E}_{\mathrm{a}}(\mathrm{ac})=0.84 \pm 0.04 \mathrm{eV}$ and $\mathrm{E}_{\mathrm{a}}(\mathrm{dc})=$ $0.87 \pm 0.04 \mathrm{eV}$.

SEM of fracture surface $\mathbf{M g Z r}_{4} \boldsymbol{P}_{6} \boldsymbol{O}_{24 \cdot}$-Figure 10 shows the micrograph of $\mathrm{MgZr}_{4} \mathrm{P}_{6} \mathrm{O}_{24}$ fracture surface ceramic pellet sintered at $1300{ }^{\circ} \mathrm{C}$. It is clear that the pellet analysed in this study shows a dense structure with little porosity which is in perfect agreement with an optimum relative density of $\sim 99 \%$ achieved at $1300{ }^{\circ} \mathrm{C}$ for the solid electrolyte. The relative density is determined from the physical dimensions and theoretical density calculated from crystal structure of the electrolyte. The EDS spectrum (i) as presented in Table V indicates the ceramic pellet homogeneity, and the elemental composition is of stoichiometric concentration. The elemental ratio $\mathrm{Mg}, \mathrm{Zr}, \mathrm{P}, \mathrm{O}$ in the selected region agrees with the anticipated stoichiometric composition of $\mathrm{MgZr}_{4} \mathrm{P}_{6} \mathrm{O}_{24}$.

Sensor for $\mathrm{Mg}$ in liquid Al-sensor testing.-The solid-state $\mathrm{Mg}$-sensor designed in this study can be schematically represented as:

$$
\begin{aligned}
& (+) \text { air, } \mathrm{Fe}-\mathrm{Cr}, \mathrm{MgCr}_{2} \mathrm{O}_{4} \\
& \quad+\mathrm{Cr}_{2} \mathrm{O}_{3}(\mathrm{~s}) / \mathrm{MgZr}_{4} \mathrm{P}_{6} \mathrm{O}_{24}(\mathrm{~s}) / \mathrm{Al}-\mathrm{Mg}(\mathrm{l}), \mathrm{Mo}(-)
\end{aligned}
$$

The measured open circuit voltage of the sensor at different $\mathrm{Mg}$ concentrations is given in Table VI and can be represented by Eq. 6:

$$
\mathrm{E} / \mathrm{V}( \pm 0.009)=2.446+0.1265 \log \mathrm{X}_{\mathrm{Mg}}
$$

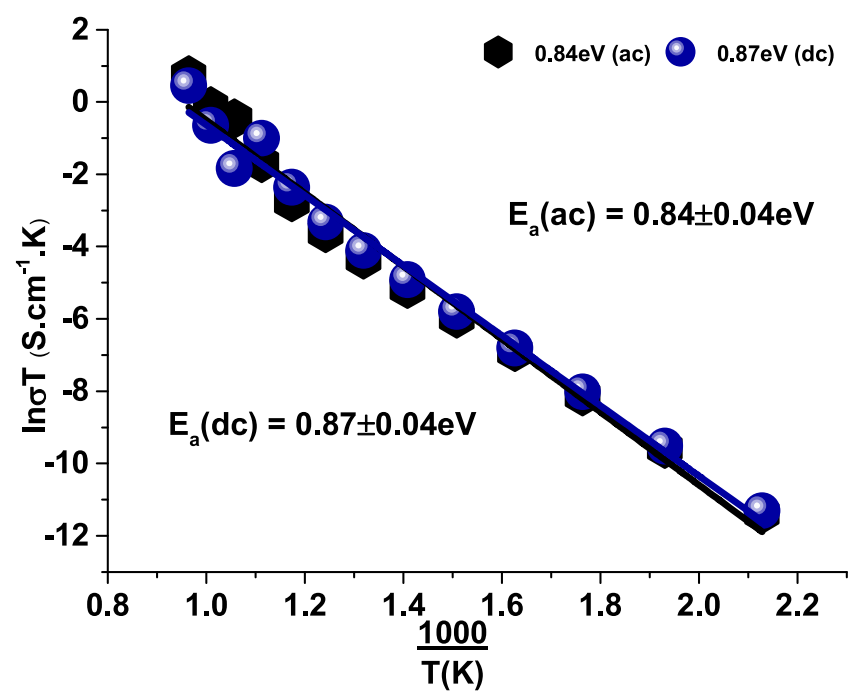

Figure 9. Comparison of dc-conductivity extracted from the low-frequency plateau with ac-conductivity of $\mathrm{MgZr}_{4} \mathrm{P}_{6} \mathrm{O}_{24}$ solid-state electrolyte calculated using Arrhenius equation. 


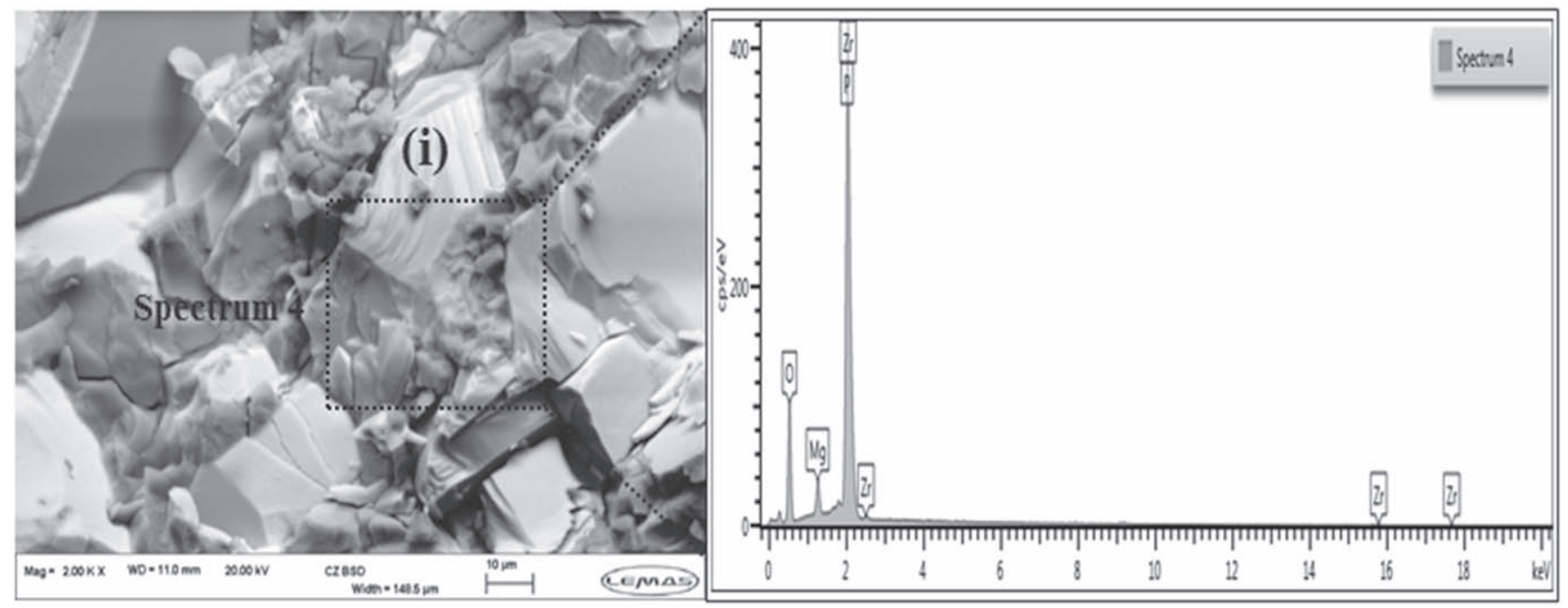

Figure 10. SEM micrographs fracture surfaces of $\mathrm{MgZr}_{4} \mathrm{P}_{6} \mathrm{O}_{24}$ ceramic pellet sintered at $1300{ }^{\circ} \mathrm{C}$ and annealed for $24 \mathrm{~h}$, showing its corresponding EDS spectrum 10(i).

The voltage generated between the dissimilar metal leads from the two electrodes $(\mathrm{Mo}(+)-\mathrm{Fe}-\mathrm{Cr}(-))$ at $700 \pm 5{ }^{\circ} \mathrm{C}$ measured independently is $-0.0093 \mathrm{~V}$. The emf of the cell corrected for
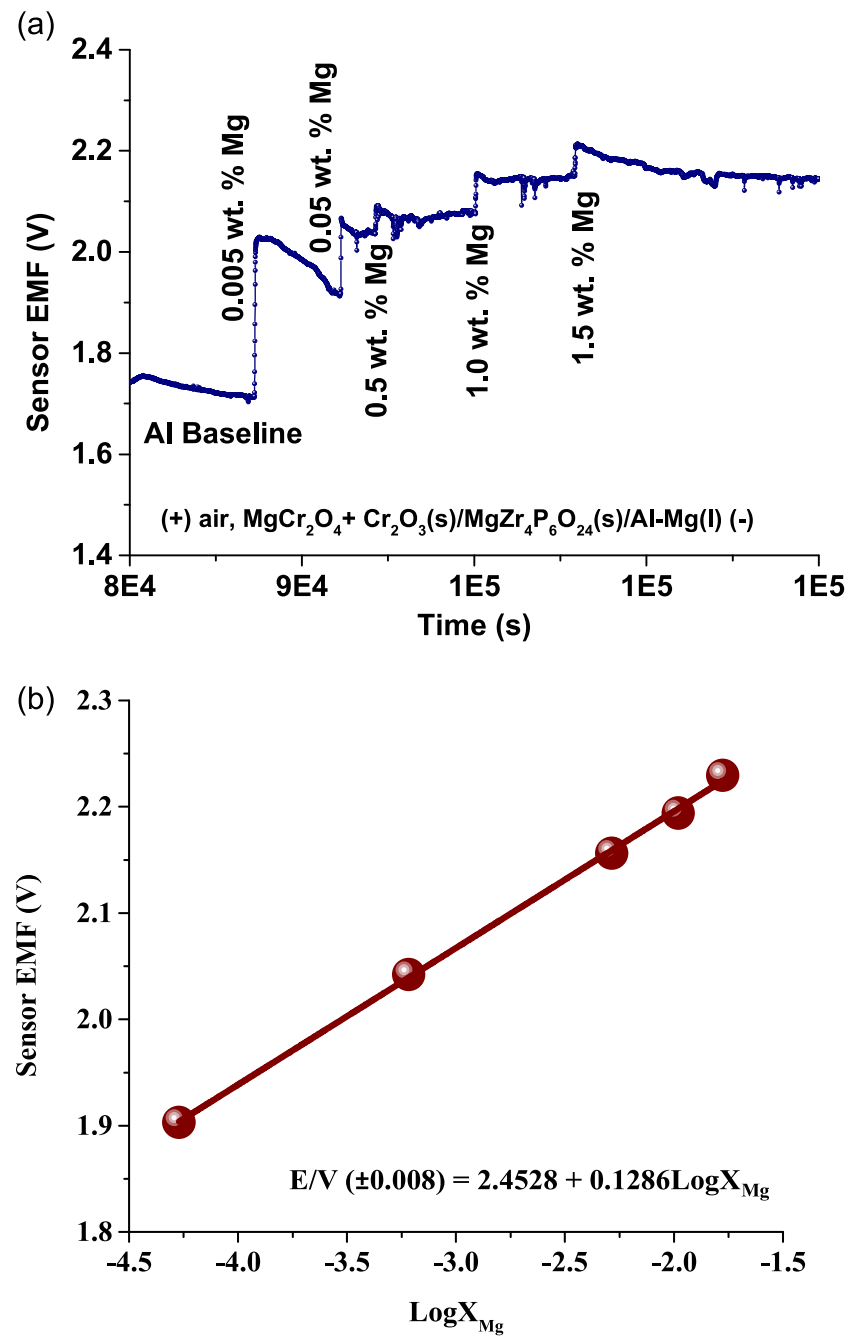

Figure 11. (a). Response of solid-state $\mathrm{Mg}$-sensor in molten $\mathrm{Al}$ as a function of time after successive addition of $\mathrm{Mg}$. (b) Sensor voltage variation of solidstate $\mathrm{Mg}$-sensor in molten $\mathrm{Al}$. thermo-emf is given by:

$$
\mathrm{E} / \mathrm{V}( \pm 0.009)=2.437+0.1265 \log \mathrm{X}_{\mathrm{Mg}}
$$

Figure 11a shows the response of $\mathrm{Mg}$-sensor to changes in the concentration of $\mathrm{Mg}$ in molten $\mathrm{Al}$ using $\mathrm{MgCr}_{2} \mathrm{O}_{4}+\mathrm{Cr}_{2} \mathrm{O}_{3}$ biphasic powder mixture as the reference electrode. Each step in Fig. 11a correspond to the addition of $\mathrm{Mg}$ in molten $\mathrm{Al}$ at $700 \pm 5{ }^{\circ} \mathrm{C}$. It shows that the sensor emf increases with the concentration of $\mathrm{Mg}$ in molten Al. The sensor response was rapid. The emf response as a function of time in Fig. 11a suggests that the solid electrolyte is chemically stable in molten $\mathrm{Al}$ at $700 \pm 5^{\circ} \mathrm{C}$. Meanwhile, instability in the sensor signal at $0.005 \mathrm{wt} \% \mathrm{Mg}$ in molten $\mathrm{Al}$ could in part be due to the possibility of reaching a limiting value for the measurement of $\mathrm{Mg}$ in molten $\mathrm{Al}$ using $\mathrm{MgZr}_{4} \mathrm{P}_{6} \mathrm{O}_{24}$ as solid electrolyte. ${ }^{59,60}$ Fig. $11 \mathrm{~b}$ shows sensor voltage variation of the solid-state $\mathrm{Mg}$-sensor in molten $\mathrm{Al}$ at $700 \pm 5{ }^{\circ} \mathrm{C}$. The measured voltage variation of this solid-state $\mathrm{Mg}$-sensor as a function of concentration of $\mathrm{Mg}$ in molten $\mathrm{Al}$ at $700 \pm 5{ }^{\circ} \mathrm{C}$ is in general agreement with the earlier findings. ${ }^{59,60}$

The activity of $\mathrm{Mg}$ is relatively high at the alloy electrode and very low at the ceramic electrode exposed to air. The electrochemical reaction at the alloy electrode on the right-hand side of the cell is:

$$
\{\mathrm{Mg}\}_{\mathrm{Al}(\mathrm{l})} \rightarrow \mathrm{Mg}^{2+}+2 \mathrm{e}^{-}
$$

At the reference electrode on the left-hand side, the electrochemical reaction is:

$$
\mathrm{Mg}^{2+}+0.5 \mathrm{O}_{2}(\mathrm{~g})+\mathrm{Cr}_{2} \mathrm{O}_{3} \text { (cor) }+2 \mathrm{e}^{-} \rightarrow \mathrm{MgCr}_{2} \mathrm{O}_{4}(\mathrm{sp})
$$

The emf $(\mathrm{E} / \mathrm{V})$ of the sensor is given by the expression

$$
E=-\frac{1}{n F} \int_{\mu_{M g}^{i i}}^{\mu_{M g}^{i}} t_{i o n} d \mu_{M g}
$$

\section{Table V. Average elemental composition of the EDS spectrum from fracture surface $\mathrm{MgZr}_{4} \mathrm{P}_{6} \mathrm{O}_{24}$ ceramic pellet sintered at $1300{ }^{\circ} \mathrm{C}$.}

\begin{tabular}{lcc} 
Element & Atomic Fraction $(\%)$ & Atomic Ratio \\
\hline $\mathrm{Mg}$ & 2.83 & 1.00 \\
$\mathrm{Zr}$ & 11.68 & 4.13 \\
$\mathrm{P}$ & 16.53 & 5.84 \\
$\mathrm{O}$ & 68.96 & 24.37 \\
Total & 100.00 &
\end{tabular}




\begin{tabular}{|c|c|c|c|c|c|}
\hline wt $\% \mathrm{Mg}$ & $\mathrm{N}_{\mathrm{Mg}}$ & $\mathrm{N}_{\mathrm{Al}}$ & $\mathrm{X}_{\mathrm{Mg}}$ & $\log X_{M g}$ & $\mathrm{E} / \mathrm{V}$ \\
\hline 0.005 & 0.0002 & 3.7063 & $5.55 \mathrm{E}-05$ & -4.2557 & 1.90 \\
\hline 0.05 & 0.0021 & 3.7046 & $5.55 \mathrm{E}-04$ & -3.2557 & 2.05 \\
\hline 0.5 & 0.0206 & 3.6879 & $5.55 \mathrm{E}-03$ & -2.2560 & 2.15 \\
\hline 1.0 & 0.0411 & 3.6694 & $1.11 \mathrm{E}-02$ & -1.9552 & 2.19 \\
\hline 1.5 & 0.0617 & 3.6509 & $1.66 \mathrm{E}-02$ & -1.7793 & 2.23 \\
\hline
\end{tabular}

Where $\mathrm{F}$ is the Faraday constant in Coulombs $\mathrm{mol}^{-1}, \mathrm{n}=2$ is the number of electrons participating in the electrode reactions, $t_{i o n}$ is the transport number of the conducting species $\left(\mathrm{Mg}^{2+}\right)$, and $\mu_{\mathrm{Mg}}$ is the chemical potential of $\mathrm{Mg}$ defined as RTlna $\mathrm{Mg}_{\mathrm{Mg}}$ where $\mathrm{a}_{\mathrm{Mg}}$ is the thermodynamic activity of $\mathrm{Mg}$, the neutral form of the conducting species in the electrolyte. It is apparent from the polarity of the cell and emf response of the sensor that, the chemical potential of $\mathrm{Mg}$ at the reference electrode $\left(\mu_{\mathrm{Mg}}^{\mathrm{ii}}\right)$ is lower than that at the molten alloy sensing electrode $\left(\mu_{\mathrm{Mg}}^{\mathrm{i}}\right)$.

If it is assumed that the transport number of $\mathrm{Mg}^{2+}$-cation in $\mathrm{MgZr}_{4} \mathrm{P}_{6} \mathrm{O}_{24}$ is unity, emf of $\mathrm{Mg}$-sensor can be calculated from the thermodynamic activity of $\mathrm{Mg}$ in molten Al. The Gibbs energy of formation of $\mathrm{MgCr}_{2} \mathrm{O}_{4}$ (sp) from its component binary oxides according to $\mathrm{Jacob}^{61}$ is given by

$$
\begin{gathered}
\mathrm{MgO}(\mathrm{rs})+\mathrm{Cr}_{2} \mathrm{O}_{3} \text { (cor) }=\mathrm{MgCr}_{2} \mathrm{O}_{4}(\mathrm{sp}) \\
\Delta \mathrm{G}_{f(\text { ox })}^{\mathrm{o}}( \pm 400) / \mathrm{J} \mathrm{mol}^{-1}=-45200+5.36(\mathrm{~T} / \mathrm{K})
\end{gathered}
$$

At $700{ }^{\circ} \mathrm{C}(973 \mathrm{~K})$;

$\Delta \mathrm{G}^{\circ}=-39985 \mathrm{~J} \mathrm{~mol}^{-1}$. Combining this with the Gibbs energy of formation of $\mathrm{MgO}$ at the same temperature

$$
\operatorname{Mg}(\mathrm{l})+0.5 \mathrm{O}_{2}(\mathrm{~g})=\operatorname{MgO}(\mathrm{s}), \Delta G_{\mathrm{f}}^{\mathrm{o}}=-501401 \mathrm{~J} \mathrm{~mol}^{-1}
$$

The Gibbs energy change associated with the virtual cell reaction at $700{ }^{\circ} \mathrm{C}$ is given by;

$$
\begin{aligned}
& \mathrm{Mg}(\mathrm{l})+\mathrm{Cr}_{2} \mathrm{O}_{3} \text { (cor) }+0.5 \mathrm{O}_{2}(\mathrm{~g})=\mathrm{MgCr}_{2} \mathrm{O}_{4}(\mathrm{sp}), \\
& \Delta \mathrm{G}^{\mathrm{o}}=-541386 \mathrm{~J} \mathrm{~mol}^{-1}
\end{aligned}
$$

The estimated uncertainty in the value of Gibbs energy change for reaction (14) is $5 \mathrm{~J} \mathrm{~mol}^{-1}$. EMF of the sensor is related to the activity of $\mathrm{Mg}$ in molten $\mathrm{Al}$ by the relation;

$$
-2 \mathrm{FE}=\Delta \mathrm{G}=\Delta \mathrm{G}^{\mathrm{o}}+\mathrm{RT}_{\ln \mathrm{M}_{\mathrm{Mg}}}+0.5 \mathrm{RT} \ln \mathrm{P}_{\mathrm{O} 2}
$$

Thus, the theoretical emf of the sensor at $700{ }^{\circ} \mathrm{C}$ can be calculated as;

$$
\mathrm{E}_{\mathrm{th}}( \pm 0.026) / \mathrm{V}=2.7728+0.09653 \log \mathrm{a}_{\mathrm{Mg}}
$$

Aghdam and Soltanieh ${ }^{62}$ measures activity of $\mathrm{Mg}$ in liquid $\mathrm{Al}$ using an electrochemical cell with the eutectic mixture of $\mathrm{MgCl}_{2}-\mathrm{CaCl}_{2}$ as an electrolyte in a temperature range from 700 to $800{ }^{\circ} \mathrm{C}$ and $\mathrm{Mg}$ composition from 0.07 to 12.1 . The activity coefficient of $\mathrm{Mg}$ at $700{ }^{\circ} \mathrm{C}$ for dilute alloys up to 1.4 atom\% $\mathrm{Mg}$ can be expressed by the relation,

$$
\log \gamma_{\mathrm{Mg}}=-0.7624+23.183 \mathrm{X}_{\mathrm{Mg}}
$$

Expressing activity of $\mathrm{Mg}$ in Eq. 16 as a product of mole fraction and activity coefficient, one obtains;

$$
\mathrm{E}_{\mathrm{th}}( \pm 0.03) / \mathrm{V}=2.6992+2.2379 \mathrm{X}_{\mathrm{Mg}}+0.09653 \log \mathrm{X}_{\mathrm{Mg}}
$$

The theoretical emf is compared with the measured values in Fig. 12. On the average, the measured values are lower by

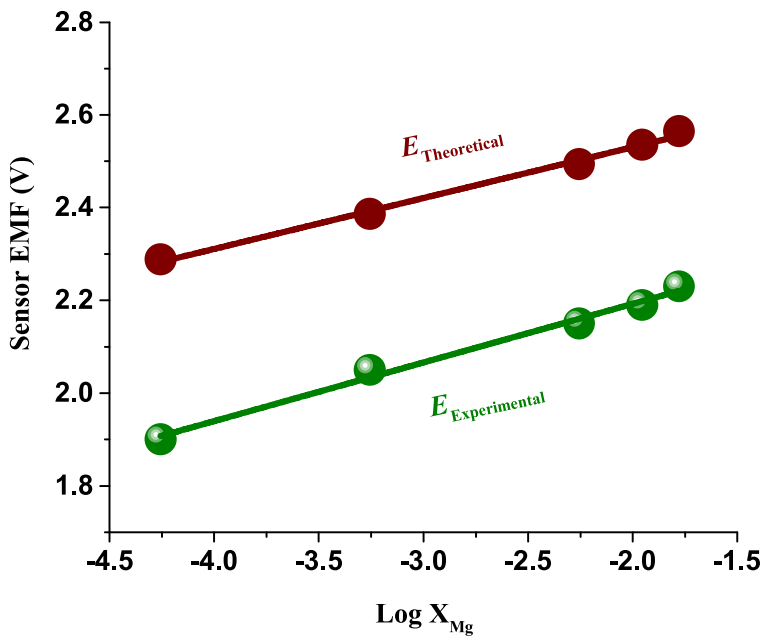

Figure 12. Comparison of the measured voltage of the sensor with the theoretical emf.

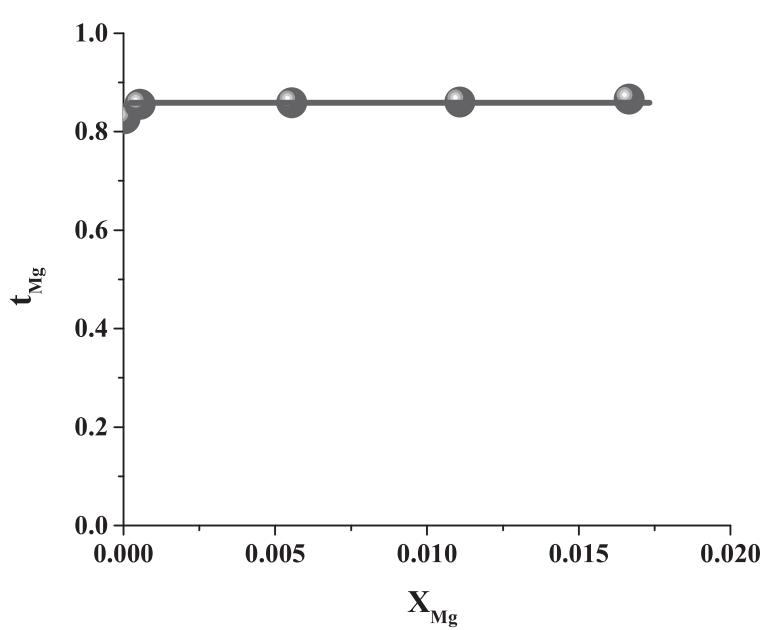

Figure 13. Variation of the average transport number of $\mathrm{Mg}^{2+}$-cations in $\mathrm{MgZr}_{4} \mathrm{P}_{6} \mathrm{O}_{24}$ at $700{ }^{\circ} \mathrm{C}$.

$\sim 0.359 \pm 0.022 \mathrm{~V}$. The average transport number at $700{ }^{\circ} \mathrm{C}$ for $\mathrm{Mg}^{2+}$-cations over the range of chemical potential at the two electrodes can be computed from the difference between experimental and theoretical emfs assuming that the electrodes are not polarised.

$$
t_{\text {ion }}=\frac{E_{\mathrm{exp}}}{E_{t h}}
$$

The average transport number for $\mathrm{Mg}^{2+}$-cations in the $\mathrm{MgZr}_{4} \mathrm{P}_{6} \mathrm{O}_{24}$ solid electrolyte obtained thus is shown in Fig. 13 as a function of $\mathrm{Mg}$ concentration. The average value is $0.85 \pm 0.03$.

The results in this study however compares favourably with the activity of $\mathrm{Mg}$ in liquid $\mathrm{Al}$ reported by Aghdam and Soltanieh. ${ }^{62}$ However, it is quite likely that the measured emf is affected by the relatively large electron-hole transport in the electrolyte and the large difference in chemical potential of $\mathrm{Mg}$ at the two electrodes leading to polarisation of the solid reference electrodes. Hence, the testing of $\mathrm{MgZr}_{4} \mathrm{P}_{6} \mathrm{O}_{24}$ solid electrolyte with other reference electrodes with higher $\mathrm{Mg}$ chemical potential is recommended.

\section{Conclusions}

According to TGA-DSC analysis and XRD data, the xerogel powder formed during sol-gel synthesis transformed to pure single-phase 
monoclinic $\mathrm{MgZr}_{4} \mathrm{P}_{6} \mathrm{O}_{24}$ after calcination at $900{ }^{\circ} \mathrm{C}$. HR-TEM measurements also confirmed the formation of $\mathrm{MgZr}_{4} \mathrm{P}_{6} \mathrm{O}_{24}$ in the range $900 \leqslant T /{ }^{\circ} \mathrm{C} \leqslant 1300$. Rietveld refinement was used to access the crystal structure parameters of $\mathrm{MgZr}_{4} \mathrm{P}_{6} \mathrm{O}_{24}$. EDS spectra confirmed that the spatial distribution of the constituent elements agree with the corresponding atomic ratio of the complex phosphate.

Dense and stable sample pellets for impedance analysis were prepared by room temperature compressive pressure consolidation and sintering of the nano size powder at $1300{ }^{\circ} \mathrm{C}$. The electrical properties of $\mathrm{MgZr}_{4} \mathrm{P}_{6} \mathrm{O}_{24}$ were determined as a function of temperature using impedance spectroscopy. The compound appears to be $\mathrm{Mg}^{2+}$-cation conductor at high temperatures for electrochemical devices and thermodynamic measurements. Sintered $\mathrm{MgZr}_{4} \mathrm{P}_{6} \mathrm{O}_{24}$ was stable at $700 \pm 5{ }^{\circ} \mathrm{C}$ in molten $\mathrm{Al}$ and $\mathrm{Al}-\mathrm{Mg}$ alloys in the range from 0.005 to $1.5 \mathrm{wt} \% \mathrm{Mg}$. The $\mathrm{MgZr}_{4} \mathrm{P}_{6} \mathrm{O}_{24}$ pellets were used to fabricate a solid-state sensor for measuring $\mathrm{Mg}$ concentration in molten Al. A biphasic powder mixture of $\mathrm{MgCr}_{2} \mathrm{O}_{4}+\mathrm{Cr}_{2} \mathrm{O}_{3}$ in air was used as reference electrode. The sensor voltage was a linear function of logarithm of the $\mathrm{Mg}$ concentration. Hence a practical sensor can be developed for remelting and casting applications. However, the sensor emf was consistently below the theoretical value suggesting an average ionic transport number of $0.85 \pm 0.03$ for $\mathrm{MgZr}_{4} \mathrm{P}_{6} \mathrm{O}_{24}$ in the temperature and $\mathrm{Mg}$ chemical potential range covered in this study.

\section{Acknowledgments}

The authors appreciate TETFund for the $\mathrm{PhD}$ fund and $\mathrm{Dr}$ Jennifer Forrester, Dr Faye Esat, Dr Zabeada Aslam, Mr Stuart Micklethwaite, Mr Mohammed Javed, and Mr Simon Lloyd for technical assistance.

The authors declare no competing financial interest.

\section{ORCID}

Mohammed Adamu (iD https://orcid.org/0000-0002-5028-9370

K. T. Jacob (DD https://orcid.org/0000-0002-4498-2742

Girish M. Kale (iD https://orcid.org/0000-0002-3021-5905

\section{References}

1. W. J. Joost and P. E. Krajewski, Scr. Mater., 128, 107 (2017).

2. J. Hirsch and T. Al-Samman, Acta Mater., 61, 818 (2013).

3. H. Friedrich and S. Schumann, J. Mater. Process. Technol., 117, 276 (2001).

4. B. L. Tiwari, J. Miner. Met. Mater. Soc., 34, 54 (1982).

5. J. W. Fergus and S. Hui, Metall. Mater. Trans. B, 26, 1289 (1995).

6. S. Barth, S. Olazcuaga, and P. Gravereau, Mater. Lett., 16, 96 (1993).

7. V. I. Pet'kov, V. S. Kurazhkovskaya, A. I. Orlova, and M. L. Spiridonova, Crystallogr. Rep., 47, 736 (2002)

8. A. Orlova, G. Y. Artem'eva, I. Korshunov, and N. P. Egorov, Zh. Neorg. Khim., 35, 1091 (1990).

9. S. Ikeda, M. Takahashi, J. Ishikawa, and K. Ito, Solid State Ionics, 23, 125 (1987)

10. K. Nomura, S. Ikeda, K. Ito, and H. Einaga, Bull. Chem. Soc. Jpn., 65, 3221 (1992)

11. K. Nomura, S. Ikeda, K. Ito, and H. Einaga, J. Electroanal. Chem., 326, 351 (1992)

12. P. C. Christidis and P. J. Rentzeperis, Zeitschrift Fur Kristallographie-Crystalline Materials, 141, 233 (1975).

13. M. Adamu and G. M. Kale, J. Phys.Chem. C, 120, 17909 (2016).
14. X. Judez, H. Zhang, C. Li, G. G. Eshetu, J. A. Gonzalez-Marcos, M. Armand, and L. M. Rodriguez-Martinez, J. Electrochem. Soc., 165, A6008 (2018).

15. P. Knauth, Solid State Ionics, 180, 911 (2009).

16. J. W. Fergus, Solid State Ionics, 227, 102 (2012).

17. S. Tamura, A. Mori, and N. Imanaka, Solid State Ionics, 175, 467 (2004).

18. Y. Hu, Y. Song, Y. Wang, and J. Di, Thin Solid Films, 519, 6605 (2011).

19. U. Sivasankaran and K. G. Kumar, J. Electrochem. Soc., 166, B92 (2019).

20. Y. Liu, H. Li, L. Lu, B. Sun, L. Huang, H. Chen, W. Qiu, J. Tao, and P. Zhao, J. Electrochem. Soc., 166, B133 (2019).

21. S. M. Ali and H. A. Al lehaibi, J. Electrochem. Soc., 165, B345 (2018).

22. E. V. Karpova, E. E. Karyakina, and A. A. Karyakin, J. Electrochem. Soc., 164, B3056 (2017).

23. J. W. Fergus and S. Hui, J. Electrochem. Soc., 143, 2498 (1996).

24. N. P. Shetti, D. S. Nayak, S. J. Malode, and R. M. Kulkarni, J. Electrochem. Soc. 164, B3036 (2017)

25. A. C. Larson and R. B. Von-Dreele, "Los Alamos National Laboratory Report." LAUR 86-748 (2004).

26. B. H. Toby, J. Appl. Crystallogr., 34, 210 (2001)

27. A. Kazakos-Kijowski, S. Komarneni, D. Agrawal, and R. Roy, Mater. Res. Bull., 23, 1177 (1988).

28. A. R. Stokes and A. J. C. Wilson, Proc. Phys. Soc., 56, 174 (1944).

29. A. R. Bushroa, R. G. Rahbari, H. H. Masjuki, and M. R. Muhamad, Vacuum, 86 1107 (2012).

30. U. Holzwarth and N. Gibson, Nat. Nanotechnol., 6, 534 (2011).

31. L. Singh, U. S. Rai, and K. D. Mandal, J. Alloys Compd., 555, 176 (2013).

32. D. Mori, K. Sugimoto, Y. Mastuda, K. Ohmori, T. Katsumata, S. Taminato, Y. Takeda, O. Yamamoto, and N. Imanishi, J. Electrochem. Soc., 166, A5168 (2019)

33. A. Paulus, S. Kammler, S. Heuer, M. C. Paulus, P. Jakes, J. Granwehr, and R. A. Eichel, J. Electrochem. Soc., 166, A5403 (2019).

34. R. A. Huggins, Ionics, 8, 300 (2002)

35. J. T. Irvine, D. C. Sinclair, and A. R. West, Adv. Mater., 2, 132 (1990).

36. J. R. MacDonald, in Impedance Spectroscopy-Emphasising Solid Materials and Synthesis, ed. J.R. MacDonald (John Wiley \& Sons, New York) (1987).

37. B. V. R. Chowdari and R. Gopalakrishnan, Solid State Ionics, 18, 483 (1986).

38. P. Ferloni and A. Magistris, J. Phys. IV France, 4, C1-3 (1994).

39. D. F. Zhou, Y. J. Xia, J. X. Zhu, and J. Meng, Solid State Sci., 11, 1587 (2009).

40. P. Yadav and M. C. Bhatnagar, Ceram. Int., 38, 1731 (2012).

41. Q. B. Bo, G. X. Sun, and J. Meng, J. Phys. Chem. Solids, 67, 732 (2006).

42. N. Imanaka, Y. Okazaki, and G. Adachi, J. Mater. Chem., 10, 1431 (2000).

43. A. K. Jonscher, Colloid. Polym. Sci., 253, 231 (1975).

44. A. K. Ivanov-Schitz and A. B. Bykov, Solid State Ionics, 100, 153 (1997).

45. A. K. Jonscher, J. Mater. Sci., 16, 2037 (1981).

46. M. D. Ingram, Phys. Chem. Glasses, 28, 215 (1987).

47. M. Sugantha and M. Varadaraju, Solid State Ionics, 95, 201 (1997).

48. C. Mariappan, G. Govindaraj, and B. Roling, Solid State Ionics, 176, 723 (2005).

49. G. Govindaraj and C. Mariappan, Solid State Ionics, 147, 49 (2002).

50. K. Funke, Prog. Solid State Chem., 22, 111 (1993).

51. M. A. Afifi, M. M. El-Nahass, A. E. Bekheet, and I. T. Zedan, Physica B, 400, 248 (2007).

52. T. Prakash, Int. Nano Lett., 2, 1 (2012)

53. C. R. Mariappan, G. Govindaraj, S. V. Rathan, and G. V. Prakash, Mater. Sci. Eng. $B, \mathbf{1 2 1}, 2$ (2005).

54. A. K. Jonscher, Nature, 267, 673 (1977)

55. L. P. Teo, M. H. Buraidah, A. F. M. Nor, and S. R. Majid, Ionics, 18, 655 (2012)

56. M. Vijayakumar, G. Hirankumar, B. Sirakumar, and S. Subramanian, J. Power Sources, 117, 143 (2003).

57. T. Savitha, S. Selvasekarapandian, C. S. Ramya, M. S. Bhuvaneswari, G. Hirankumar, R. Baskaran, and P. C. Angelo, J. Power Sources, 157, 533 (2006)

58. A. M. Abo El Ata, S. M. Attia, and T. M. Meaz, Solid State Sci., 6, 61 (2004).

59. G. M. Kale, L. Wang, and Y. Hong, Int. J. Appl. Ceram. Technol., 1, 180 (2004).

60. G. M. Kale, K. T. Jacob, L. Wang, and Y. Hong, ECS Trans., 1, 1 (2006).

61. K. T. Jacob, J. Electrochem. Soc., 124, 1827 (1977).

62. G. R. K. Aghdam and M. Soltanieh, Can. Metall. Q., 49, 39 (2010). 